\title{
Age, spreading rates, and spreading asymmetry of the world's ocean crust
}

\author{
R. Dietmar Müller ${ }^{1,{ }^{*}}$, Maria Sdrolias ${ }^{1}$, Carmen Gaina ${ }^{2}$ and Walter R. Roest ${ }^{3}$
}

\footnotetext{
${ }^{1}$ EarthByte Group, School of Geosciences, Building H11, The University of Sydney, NSW 2006, Australia

${ }^{2}$ Center for Geodynamics, Geological Survey of Norway, Leiv Eirikssons vei 39, N-7491, Trondheim, Norway

${ }^{3}$ Département Géosciences Marines, Ifremer, BP 70, 29280 Plouzané, France
}

*: Corresponding author : R. Dietmar Müller, email address : $\underline{\text { d.muller@usyd.edu.au }}$

\begin{abstract}
:
We present four companion digital models of the age, age uncertainty, spreading rates, and spreading asymmetries of the world's ocean basins as geographic and Mercator grids with 2 arc min resolution. The grids include data from all the major ocean basins as well as detailed reconstructions of back-arc basins. The age, spreading rate, and asymmetry at each grid node are determined by linear interpolation between adjacent seafloor isochrons in the direction of spreading. Ages for ocean floor between the oldest identified magnetic anomalies and continental crust are interpolated by geological estimates of the ages of passive continental margin segments. The age uncertainties for grid cells coinciding with marine magnetic anomaly identifications, observed or rotated to their conjugate ridge flanks, are based on the difference between gridded age and observed age. The uncertainties are also a function of the distance of a given grid cell to the nearest age observation and the proximity to fracture zones or other age discontinuities. Asymmetries in crustal accretion appear to be frequently related to asthenospheric flow from mantle plumes to spreading ridges, resulting in ridge jumps toward hot spots. We also use the new age grid to compute global residual basement depth grids from the difference between observed oceanic basement depth and predicted depth using three alternative age-depth relationships. The new set of grids helps to investigate prominent negative depth anomalies, which may be alternatively related to subducted slab material descending in the mantle or to asthenospheric flow. A combination of our digital grids and the associated relative and absolute plate motion model with seismic tomography and mantle convection model outputs represents a valuable set of tools to investigate geodynamic problems.
\end{abstract}

Keywords: digital isochrons; ocean floor; plate kinematic; geodynamic; seafloor spreading. 


\section{Introduction}

The gridded seafloor isochrons of Müller et al. [1997] represent a widely used resource in a variety of fields ranging from marine geology and geophysics, global seismology, geodynamics and education. However, this grid contains many gaps corresponding to ocean floor that was poorly mapped at the time when the grid was assembled. They include parts of the southern and central eastern Indian Ocean, parts of the Late Cretaceous ocean crust in the southwest Pacific and many back-arc basins. Also, no spreading rate or spreading asymmetry grids were constructed at that time. Here we present a new set of grids, including a complete grid of oceanic crustal ages without gaps, based on a revised set of global plate rotations (Supplementary Table 1), as well as gridded sea floor spreading half rates and spreading asymmetry.

\section{Methodology}

The locations and geometry of mid ocean ridges through time are represented by seafloor isochrons, reconstructed on the basis of marine magnetic anomaly identifications and fracture zones identified from marine gravity anomalies [Sandwell and Smith, 1997] and a global set of finite rotations (Supp. Table 1). We follow the interpolation technique outlined by Müller et al. [1997], and use the timescales of Cande and Kent [1995] and Gradstein et al. [1994]. In the main ocean basins, our seafloor isochrons are constructed for the same chrons as those used by Müller et al. [1997], namely chrons 5o (10.9 Ma), 60 (20.1 Ma), 13y (33.1 Ma), 180 (40.1 Ma), 210 (47.9 Ma), 25y (55.9 Ma), 31y (67.7 Ma), 34y (83.5 Ma), M0 (120.4 Ma), M4 (126.7 Ma), M10 (131.9 Ma), M16 (139.6 Ma), M21 (147.7 Ma), and M25 (154.3 Ma). However, in back-arc basins, as well as in the Coral and Tasman seas, we construct isochrons at 
denser intervals, using chrons 10 (0.8 Ma), 2Ay (2.6 Ma), 3n4o (5 Ma), 5o (10.9 Ma), 5Dy (17.3 Ma), 6o (20.1 Ma), 6By (22.6Ma), 7o (25.2 Ma), 8o (26.6 Ma), 9o (28.0 Ma), 10o (28.7 Ma), 11y (29.4 Ma), 13y (33.1 Ma), 15o (35.0 Ma), 16y (35.3 Ma), 17o (38.1 Ma),18o (40.1 Ma), 19o (41.5 Ma), 20o (43.8 Ma), 21o (47.9 Ma), 22o (49.7 Ma), 24o (53.3 Ma), 25y (55.9 Ma), 26o (57.9 Ma), 27y (60.9 Ma), 30y (65.6 Ma), 32y (71.1 Ma), 33y (73.6 Ma), 33o (79.1 Ma), 34y (83.5 Ma), where "y" stands for young end of chron and "o" for old end of chron. The resulting gridded ages of the ocean floor are shown in Fig. 1a.

\section{Error analysis}

An age uncertainty grid is constructed following the approach of Müller et al. [1997], but in addition based on reconstructing 40,000 magnetic anomaly identifications to their conjugate

ridge flanks for constraining the uncertainty in isochron locations and geometries (Fig. 1b). This satisfies the requirement that any given seafloor isochron is based on magnetic anomaly data from both conjugate ridge flanks, at least where both flanks are preserved. The accuracy of the age grid varies not only due to the spatially irregular distribution of ship track data in the oceans, but also due to the existence of the Cretaceous Normal Superchron from about 118 to 83 Ma. Other sources of errors are given by our chosen spacing of isochrons as listed before, between which we interpolated linearly. We assume that age grid errors depend on the distance to the nearest data points and to a lesser extent on the proximity to fracture zones. In order to estimate the accuracy of our age grid, we construct a grid with age-error estimates for each grid cell dependent on (1) the error of ocean floor ages identified from magnetic anomalies (Fig. 2) along ship tracks and the age of the corresponding grid cells in our age grid, (2) the distance of a given grid node to the nearest magnetic anomaly identification, and (3) the gradient of the age grid, i.e. larger errors are associated with high age gradients across fracture zones or other age discontinuities. The latter also reflects that, due to the interpolation process, uncertainty in the 
magnetic anomaly will induce larger age errors in regions of slow spreading rates than in regions of fast spreading rates.

We first compute the age differences between $~ 45000$ interpreted magnetic anomaly ages and the ages from our digital age grid, and investigate the size and distribution of the resulting age errors. We find that the majority of errors are smaller than $1 \mathrm{~m} . \mathrm{y}$. and errors larger than $10 \mathrm{~m} . \mathrm{y}$. are mostly due to erroneously labeled or interpreted data points. We set a generous upper limit for acceptable errors as 15 m.y. As a lower limit we arbitrarily choose 0.5 m.y., since we do not expect to resolve errors smaller than $0.5 \mathrm{~m}$.y. given the uncertainty in the timescales used. We grid the remaining age errors by using continuous curvature splines in tension.

The constraints on the ages in our global age grid generally decrease with increasing distance to the nearest interpreted magnetic anomaly data point. Areas without interpreted magnetic anomalies include east-west spreading mid-ocean ridges in low latitudes such a the equatorial Atlantic ocean, where the remanent magnetic field vectors are nearly parallel to the mid-ocean ridge and cause very small magnetic anomalies, and areas containing crust formed in the Cretaceous Normal Superchron, such as in the southwest Pacific Ocean and offshore eastern India (Fig. 1b)..

In order to address the "tectonic reconstruction uncertainties" for these areas, we create a grid containing the distance of a given grid cell to the nearest data point, ranging from zero at the magnetic anomaly data points to 10 at distances of $1000 \mathrm{~km}$ and larger. We smooth this grid using a cosine arch filter ( $5^{\circ}$ full width) and add the result to the initial splined grid of age errors. Fracture zones are usually several tens of km wide, containing highly fractured and/or serpentinized ocean crust. Age estimates may be uncertain especially near large-offset fracture zones, which are more severely affected by changes in spreading direction than small-offset fracture zones. Consequently, our age estimates along large-offset fracture zones may be more uncertain than at small-offset fracture zones or on "normal" ocean crust. Large-offset fracture 
zones are easily identified in the age grid by computing the gradient of the age grid. We identify the age gradients associated with medium- to large offset fracture zones, set the gradients of "normal" ocean crust to zero, and scale the grid to range from one to two. After multiplying the error grid with the smoothed age gradients along fracture zones, we have not altered the errors associated with "normal" ocean floor, and increased the errors at fracture zones by a factor between one and two, depending on the magnitude of the age gradient. The resulting merged grid of all uncertainties is finally smoothed with a 0.8 degree full width cosine arch filter and is shown in Figure $1 b$.

\section{Spreading rate and asymmetry}

Based on our seafloor isochrons and rotation model, we have calculated seafloor spreading half rates (Fig. 3a) and relative proportions of crustal accretion (i.e. spreading asymmetry) on conjugate ridge flanks (Fig. 3b). Half spreading rates are based on stage rotations computed from our set of finite reconstruction rotations, and spreading asymmetry estimates are based on determining the percentage of crustal accretion between pairs of adjacent isochrons by dividing the angular distance between them by the half-stage rotation angle. As a result, relative crustal accretion rates of conjugate plates (Fig. 3b) can be computed by linear interpolation along isochrons and gridding, following the same methodology as that used for gridding isochron ages. In areas where only one of two ridge flanks is preserved, computed spreading asymmetries correspond to local deviations in individual spreading corridors from the average distance between two isochrons. We have masked those areas in the Pacific crustal accretion grid that lack conjugate ridge flanks. However, we have not masked the abyssal plains west of Australia in our grid showing crustal accretion percentages (Fig. 3b) because several well-known large ridge jumps away from Australia, which transferred large areas of Indian ocean crust to the Australian Plate [Mihut and Müller, 1998; Müller, et al., 2000], are outlined well by mapping deviations from the average distance between adjacent isochrons. Spreading velocities and the 
ridge-normal rates of ridge migration relative to the mantle can then be computed to investigate the patterns and causes of spreading asymmetry. Both the central North Atlantic and the western Pacific ridges show a sharp pulse of fast spreading rates around 150 Ma. This sharp increase in rates may reflect a potential time scale miscalibration.

\section{Regional review of tectonic reconstructions}

Compared with the digital isochrons of Müller et al. [1997], our model of the distribution of oceanic crustal age, has been improved considerably. The improved isochrons are accompanied by an updated set of finite rotations (Supp. Table 1). In the following we review our revised plate model region by region. In the Arctic we have included a revised model for the opening of the Amerasian Basin [Gaina, et al., 2007] for which we adopt a model for rifting of Arctic microcontinents off the North American margin in the Early to Mid-Cretaceous (142 to $120 \mathrm{Myr}$ ago), triggered by the subduction of the Anyui Ocean [Sokolov, et al., 2002]. In this model the Canada Basin forms by seafloor spreading occurring between the North American plate and the North Slope/Northwind Ridge [Gaina, et al., 2007]. The North Atlantic reconstructions are mainly based on the model by Gaina et al. [2002] (Fig. 4). Our model implies the existence of oceanic crust in Baffin Bay formed between chrons 31 and 13. However, the oblique opening at extremely slow rates (Fig. 4) may have resulted in amagmatic extension and mantle exhumation and serpentinization, as suggested by seismic refraction data [Reid and Jackson, 1997].

Our tectonic model includes the reconstruction of synthetic Neotethys ocean floor isochrons between Eurasia and Africa, following the model by Stampfli and Borel [2002], which suggests that the east Mediteranean ocean floor formed when the Cimmerian blocks rifted off Gondwanaland in the Late Permian. The Ionian Sea and the east Mediterranean basins therefore represent the oldest preserved in-situ ocean floor, ranging in age from about $270 \mathrm{Ma}$ (Late Permian) to $230 \mathrm{Ma}$ (Middle Triassic) according to our model (Fig. 2), contrasting common wisdom that the oldest in-situ ocean floor is found in the West Pacific, and is Jurassic in age. 
This model is supported by geophysical characteristics of the Ionian and east Mediterranean basins (e.g. isostatic equilibrium, seismic velocities, elastic thickness), suggesting that the age of the seafloor must be older than Early Jurassic [Stampfli and Borel, 2002]. The model is also supported by the subsidence pattern of areas such as the Sinai margin, the Tunisian Jeffara rift, Sicily and Apulia, all indicating a Late Permian onset of thermal subsidence along the Ionian Sea and east Mediterranean margins [Stampfli and Borel, 2002]. Triassic ocean floor ages in this area are also consistent with Triassic MORB found in Cyprus (Mamonia complex) [Lapierre, et $a l .$, 2007], representing intra-plate volcanism believed to have been erupted in the Neotethys. Late Permian Hallstatt-type pelagic limestone in Oman directly overlies mid-ocean ridge basalts, also suggesting that Late Permian oceanic crust was formed in the region [Stampfli and Borel, 2002]. There is evidence that the Levant Basin (adjacent to Lebanon, Israel) has a Triassic opening age [Garfunkel, 2004] and there is additional evidence for Permian rifting. Lastly, the Northeast African margin and Herodotus Basin (between Crete and Cyprus) is at least middle Jurassic in age, but may well be older and similar in age to the Levant Basin [Garfunkel, 2004]. Our reconstruction of the Liguro-Provencal Basin (Fig. 4) is based on the tectonic model and rotations from Speranza et al. [2002], describing a Miocene counterclockwise rotation of Corsica-Sardinia relative to Iberia and France. The central North and South Atlantic models (Fig. 5) are based on the reconstructions by Müller et al. [1998a] for chron 34 and younger, whereas older reconstructions are unchanged from Müller et al. [1997]. Our isochrons of the Scotia Sea (Fig. 1a) are a simplified representation of the models by Barker [2001] and Eagles et al. [2005].

Major gaps in the digital isochrons of Müller et al. [1997] have been filled in the Indian Ocean (Fig. 6). The Mesozoic Enderby Basin represents an area only recently geophysically mapped. It has been reconstructed based on the work by Gaina et al. [2007; 2003], and revised isochrons for the abyssal plains west of Australia are from Heine et al. [2004]. Both areas are 
characterized by large spreading asymmetries. West of the Perth Abyssal Plain, a large portion of Indian Ocean floor was left on the Australian Plate due to a westward ridge jump within the Cretaceous Normal Superchron (Fig. 6). Similarly, a major northward ridge jump from the Enderby Basin to the north around Chron M2 created Elan Bank as a microcontinent and left an extinct mid-ocean ridge in the Enderby basin (Fig. 6). Post 100 Ma rotations between Africa and Antarctica have been updated [Bernard, et al., 2005; Marks and Tikku, 2001; Nankivell, 1998]. We have adopted a model similar to that proposed by Marks and Tikku [2001] for the early opening of the Somali Basin and the conjugate Mozambique Basin and Riiser-Larsen Sea in which the reconstructed position of Madagascar relative to the Gunnerus Ridge is further east than that implied by the model used by Müller et al. [1997], who reconstructed Madagascar to a fit-position west of the Gunnerus Ridge. The Argo Abyssal Plain and the associated passage of "Argo Land" across the Tethys Ocean and subsequent accretion to Eurasia is reconstructed following Heine and Müller [2005]. Reconstructions of the Gascoyne Abyssal Plain are also based on Heine and Müller [2005]. An alternative model for the interpretation of magnetic lineations in this area was presented by Robb et al. [2005]; however, these authors did not develop a plate tectonic model or derive plate rotations, which makes it difficult to test their model as an alternative. Our model for the Cuvier Abyssal Plain is based on Mihut and Müller [1998] and [Mihut, 1997], whereas the model for the Perth abyssal Plain is from Mihut [1997]. Following Stampfli and Borel [2002] and Heine et al. [2004] our model includes reconstructions of the major plates constituting the eastern Neo-Tethys ocean.

The remainder of the Indian Ocean isochrons and reconstructions are taken from Müller et al. [Müller, et al., 1997]. Reconstructions and isochrons of the Tasman and Coral seas are from Gaina et al. [1998; 1999], and the outlines and relative motion history of microcontinents in the Tasman Sea as well as the remainder of the Indian and Atlantic oceans is based on Gaina et al. [2003; 2007]. 
The model for relative motion between East and West Antarctic including isochrons for the Adare Trough is from Cande et al. [2000]. Davey et al. [2006] re-evaluated the rotation pole position for the opening between East and West Antarctica. However, due to problems associated with a rotation pole located close to the geographic South Pole as they suggest (see discussion in Müller et al. [2007]) we use the model by Cande et al. [2000]. Weddell Sea isochrons and rotations are based on the model presented by König and Jokat [2006]. Southwest Pacific plate rotations are based on Cande et al. [1995] (Fig. 7) whereas the Late Cretaceous West Pacific ocean floor east of the Tonga-Kermadec subduction zone is reconstructed by combining data from Munschy [1996] with geophysical data constraining the location of the Osbourn Trough, representing an extinct mid-ocean ridge between the Pacific and Phoenix plates [Billen and Stock, 2000]. Central Pacific Ocean isochrons and rotations (Fig. 7) were constructed by using Munschy et al.'s [1996] magnetic anomaly identifications to revise Müller et al's [1997] isochrons, and Pacific-Cocos and Rivera plate reconstructions (Fig. 8) are based on Wilson [1996]. The Bauer microplate in the east Pacific was reconstructed based on the data and rotations of Eakins and Lonsdale [2003]. Mesozoic isochrons in the west Pacific, reflecting spreading between the Farallon, Phoenix and Izanagi plates, are reconstructed based on the magnetic lineations mapped by Nakanishi et al. [1989; Nakanishi, et al., 1992], whereas the northeast Pacific isochrons and rotations are largely based on the detailed tectonic maps of Atwater and Severinghaus [1990], mostly unchanged from the model used by Müller et al. [1997] with the exception of Kula Plate isochrons and rotations. Our revised Kula plate reconstructions are based on Lonsdale [1988]. We model the initiation of Kula-Pacific spreading at Chron 33, the oldest clearly identifiable magnetic anomaly related to Kula-Pacific spreading. Kula-Pacific spreading ceased at $41 \mathrm{Ma}$ with a small portion of the Kula ridge is still preserved in the north Pacific [Lonsdale, 1988]. Seafloor ages for the Gulf of Mexico and Cayman Trough (Fig. 8) are taken from Müller et al.'s [1997] isochrons. The tentative oceanic basement ages (ie 
the basement underneath the Caribbean Large Igneous Province) we show in the Caribbean are based on the intrusion of a portion of the Farallon Plate between North and South America [Pindell and Barrett, 1987], destroying the proto-Caribbean crust that had formed during the Early Cretaceous separation between North and South America [Ross and Scotese, 1988]. However, the uncertainties in the oceanic ages shown here are likely substantially larger than the age errors shown in Fig. $1 \mathrm{~b}$ for this region. A major improvement over the global isochron chart of Müller et al. [1997] is the inclusion of all circum-Pacific back-arc basins [Sdrolias and Müller, 2006; Sdrolias, et al., 2003a; Sdrolias, et al., 2003b] and southeast Asian marginal basins [Gaina and Müller, 2007], illustrated in Fig. 9. A detailed review of our interpretation of the magnetic anomalies in these basins and a discussion of tectonic models can be found in the papers listed above.

\section{Oceanic residual basement depth}

The origin of oceanic residual basement depth anomalies is still controversial. Phipps-Morgan and Smith [1992] proposed that asymmetries in the depth-age curve for conjugate ridge flanks are primarily a function of asthenospheric flow. In their model two major parameters that govern the asymmetries in depth-age behavior of oceanic lithosphere are absolute plate motion velocities, determining shear-induced asthenospheric flow, and the locations of hotspots near mid-ocean ridges, causing pressure-induced flow towards and along ridges. Following the idea that spreading asymmetry, basement depth anomaly and asthenospheric flow normal to the ridge axis may be causally connected, the relationship between long-term asymmetries in spreading and asymmetries in oceanic basement subsidence can be evaluated, but this requires the construction of a residual basement depth grid, based on selected age-depth curves (Fig. 10). Alternatively, residual basement depth anomalies may reflect deeper mantle flow. Steinberger [2007] used a mantle flow model based on several alternative mantle seismic tomography models to compute the vertical flow rate globally at 410 and $660 \mathrm{~km}$ depth. For example 
underneath the Argentine Basin in the southwest South Atlantic, a well-known negative residual depth anomaly usually attributed to asthenospheric flow [Hohertz and Carlson, 1998; Phipps Morgan and Smith, 1992], the negatively buoyant slab material sinking underneath the region causes a downward flow rate of over $2 \mathrm{~cm} / \mathrm{year}$ at both 410 and $660 \mathrm{~km}$, suggesting an alternative deep origin for the basement depth anomaly in this area, as opposed to shallow asthenospheric flow. We present a set of digital residual basement depth grids accompanied by maps of past subduction zone locations since 140 Ma and seismic tomography cross-sections that may prove useful for investigating the processes associated with residual depth anomalies. Three residual basement depth grids are shown in Fig. 11, based on the difference between sediment unloaded basement and the predicted basement depth from converting crustal age to basement depth using alternatively the GDH-1 age-depth relationship [Stein and Stein, 1992], Crosby's [2007] plate model, as well as the North Pacific thermal boundary layer model from Crosby et al. [2006] (Fig. 10). Crosby's [2007] age-depth curve corresponds to a best-fit thermal boundary layer subsidence function mostly based on the data presented in Crosby et al. [2006], with some additional data from the Southeast Atlantic Ocean added (see Crosby [2007] for details) with a damped sinusoidal perturbation added. This approach is based on the observed sinusoidal shallowing of the reference depth-age curve for the North Pacific (and to a lesser extent the North Atlantic) between the ages of 80 and130 Ma [Crosby, et al., 2006].

Crosby et al. [2006] argued that this sinusoidal shallowing is distinctive, and resembles the results of early numerical experiments of the onset of convection under a cooling lid. In these experiments, the boundary layer cools by conduction and then becomes unstable once its local Rayleigh number exceeds a critical value. The growing instability then suddenly increases as the base of the lithospheric boundary layer falls off and is replaced by hotter asthenosphere from below. The new material then cools again by conduction, until it in turn becomes unstable, 
resulting in a series of decaying oscillations about an asymptotic steady-state value, as reflected in Crosby's [2007] age-depth curve (Fig. 10).

Our new global oceanic age grid provides an opportunity to apply these alternative age-depth models to all mapped ocean crust to produce alternative residual basement depth grids as shown in Fig. 11 and to evaluate their similarities and differences. Sediment unloading is accomplished using the sediment thickness map from Divins [2004] (which excludes areas between $70^{\circ}$ of latitude and the geographic poles) and the relationship between sediment thickness and isostatic correction is from Sykes [1996]. Overall the two residual basement depth grids based on the GDH-1 and Crosby plate models (Figs. $11 \mathrm{a}$ and b) are extremely similar. As expected, the main positive residual basement depth anomalies are associated with hotspot tracks and swells. Negative residual basement depth anomalies are seen in some, but not all, back-arc basins in the southwest Pacific Ocean, the Australian-Antarctic Discordance, the Bay of Bengal east of India, in the Argentine Basin in the South Atlantic, and in part of the western central North Atlantic off the east coast of North America (Figs. 11a, b). Depth anomalies could arise from inaccuracies in our gridded ages, but in our current grid the only area where this remains a problem is in the Pacific, where some ridge jumps are not yet sufficiently incorporated in our model. Depth anomalies could also arise from crustal thickness variations and inaccurate sediment thickness estimates, and they are inherently dependent on a given model for converting crustal age to depth.

The differences between the two residual basement grids based on GDH-1 [Stein and Stein, 1992] (Fig. 11a) and Crosby [2007] (Fig. 11b) range from -205 to $140 \mathrm{~m}$, with a mean difference of only $18 \mathrm{~m}$ and a median difference of $57 \mathrm{~m}$. This implies that for practical purposes, aimed at investigating large-scale depth anomalies, these two alternative approaches yield close to identical residual basement depth maps, considering the amplitude of many of the large basement depth anomalies reproduced in both grids. The main difference between the grids lies 
in the decaying oscillations for ocean floor older than 80 million years predicted by Crosby's [2007] age-depth curve (Fig. 10). In contrast, if Crosby et al's [2006] North Pacific reference thermal boundary layer model is used to compute a global oceanic residual basement depth grid, large positive depth anomalies are ubiquitous for ocean floor older than 80-100 Ma, with notable exceptions being the Argentine Basin in the southwestern South Atlantic and the Phillipine Sea, which appear as a blue-green negative depth anomalies in all maps in Fig. 11, as well as the Bay of Bengal offshore eastern India. The large depth anomaly shown on all maps on Fig. 11 for the latter area may be at least partly an artefact due to the anomalously large sediment thickness in this area, which is insufficiently accounted for in Sykes' [1996] isostatic correction formula. That plate models such as those shown in Fig. 10 are a better approximation for the thermal structure of the oceanic lithosphere than thermal boundary layer models gained recent support by Priestley and McKenzie's [2006] determination of Pacific oceanic lithospheric thickness from shear wave velocities. They showed that the mantle temperature underneath the Pacific at 150 $\mathrm{km}$ depth is within $20^{\circ} \mathrm{C}$ of $1400^{\circ} \mathrm{C}$ throughout the Pacific area with the exception of island arcs.

\section{Origin of crustal accretion asymmetries and basement depth anomalies}

Beyond the many improvements in our digital model of seafloor isochrons summarized above, an innovation presented here are the global grids of sea floor spreading half rates and spreading asymmetries (Fig. 3 and Figs, 4-9), as well as our maps of past subduction zone locations since $140 \mathrm{Ma}$, paired with shear-wave seismic tomography cross-sections (Fig. 12). Together with our relative and absolute plate rotation model (Supp. Table 1) and other published data, such as digital grids for bathymetry [Smith and Sandwell, 1994], gravity anomalies [Sandwell and Smith, 1997], sediment thickness [Divins, 2004] and mantle convection driven dynamic surface and transition zone topography [Steinberger, 2007], these data sets provide a powerful tool to investigate geodynamic problems. Here we restrict ourselves to briefly review the relationship 
between selected crustal accretion asymmetries, basement depth anomalies, mantle structure and relative and absolute plate motions.

Müller et al. [1998b] found that there is no clear causal relationship between absolute plate motion velocities and the large-scale asymmetry of spreading, except for when ridge migration rates relative to the mantle have been as high as between India and Antarctica after chron 34 (83.5 Ma). Excess accretion between $3 \%$ and $7 \%$ has occurred on the Antarctic plate conjugate to India since chron 18 (40 Ma), while the Indian plate moved northward at average speeds of $\sim 40-80 \mathrm{~mm} /$ a relative to a slowly moving Antarctic plate (trailing ridge flank faster) (Fig. 3b) [Müller, et al., 1998b]. In Figure 3b, this is reflected by crustal accretion values of 53 to $57 \%$ for the Antarctic Plate, paired with values of 47 to $43 \%$ on the conjugate Indian Plate. In contrast, the South American ocean floor conjugate to Africa shows excess accretion averaging 3-4\% (leading ridge flank faster), corresponding to crustal accretion percentages averaging 53-54 \% on the South American ridge flank in Fig. 3b. Where plate-wide asymmetries are observed on average, they do not occur in all spreading corridors (Fig. 3b). Instead it appears that asthenospheric flow from hotspots to nearby mid-ocean ridges exerts a larger control on spreading asymmetries than absolute ridge migration velocities, as we observe deficits in crustal accretion on ridge flanks close to mantle plumes (Fig. 3b). This observation, discussed in detail by Müller et al. [1998b], highlights the relevance of asthenospheric flow between hotspots and nearby ridges for causing consecutive ridge jumps and/or propagation events towards a given hotspot, as well as gaps in hotspot tracks [Sleep, 2002]. Our detailed circum-Pacific back-arc basin reconstructions and isochrons (Fig. 9) frequently show net excess accretion on the remnant arc side. This is seen in the Shikoku Basin, consistent with earlier observations by Barker and Hill [1980], the Parece Vela Basin and parts of the South Fiji Basin (Fig. 9). The South China Sea displays net excess accretion on its northern, landward side (Fig. 9). These results may be useful as constraints for subduction models 
including absolute and relative plate motions, subduction hinge kinematics, mantle convection and mantle wedge properties to better understand active margin processes.

The largest asymmetries in crustal accretion we find anywhere in the Atlantic and Indian oceans have occurred in the central and southern South Atlantic oceans, with an average of over 3.5\% excess accretion on South America [Müller, et al., 1998b]. However, the corridors with the largest asymmetries in accretion are not identical to those corridors which show the largest positive asymmetries in subsidence, e.g. in the Argentine Basin (see also Calcagno and Cazenave [1994] for a detailed analysis of ocean floor subsidence in the Atlantic ocean). Instead those ridge segments proximal to mantle plumes display consecutive jumps towards the hotspots, resulting in the observed asymmetries, which are particularly pronounced in the spreading corridors associated with the Tristan Da Cunha and Discovery plumes for the time period while the plumes have been close to the ridge during the last 30 million years (Fig. 5).

In the central North Atlantic we find cumulative excess accretion of only $1 \%$ on North America during the last 130 m.y., even though the ridge migration rate is three times that in the South Atlantic. The relatively large asymmetries in accretion on the South Atlantic appear to be a product of ridge-hotspot interaction and the lack of cumulative asymmetries larger than $1 \%$ in the central North Atlantic reflect a lack of mantle plumes close to the ridge during most of its opening history. Therefore we conclude that absolute plate motion velocities do not appear to drive either processes resulting in asymmetries in subsidence or asymmetric accretion of ocean crust in the Atlantic Ocean.

Spreading asymmetries as well as depth anomalies may both be related to asthenospheric flow. In the central Indian Ocean we observe a correlation between negative depth anomalies and asymmetries in accretion between Kerguelen and the westernmost segments of the Southeast Indian ridge on a relatively small scale (Fig. 3b). Here asthenospheric material appears to be channelled to the mid-ocean ridge, resulting in anomalously shallow topography, as well as 
excess accretion on the Australian ridge flank. A similar situation may exist east of the Australian-Antarctic Discordant Zone at latitudes $130^{\circ} \mathrm{E}$ to $139^{\circ} \mathrm{E}$, where a negative depth anomaly is observed centered on the Antarctic ridge flank [Hayes, 1988], in concert with excess accretion on the Australian ridge flank (Fig. 6). However, it is doubtful that this reflects asthenospheric flow, which in this case would be from the Balleny hotspot southeast of these crustal accretion asymmetries towards the southeast Indian Ridge, because that the Balleny plume is regarded as either a secondary hotspot formed from the lateral flow of plume material toward thin lithosphere from beneath Antarctica or as the product of non-plume volcanism associated with lithospheric cracks [Sleep, 2006].

The fast spreading East Pacific Rise between the Nazca and Pacific plates (Fig. 5) exhibits much larger asymmetries in crustal accretion than any plate pair in the Atlantic and Indian oceans. Excess accretion on the Nazca plate reached up to $70 \%$ and larger during the last 40 million years, without any clear relationship with ridge migration rates, as this spreading ridge has migrated quite slowly in a Pacific hotspot frame, with rates varying between 19 and $0.1 \mathrm{~mm} / \mathrm{yr}$ in the last 40 m.y., averaging about $8 \mathrm{~mm} / \mathrm{yr}$ [Müller, et al., 1998b]. These crustal accretion asymmetries along the East Pacific Rise have resulted in long-term excess accretion on the Nazca Plate, implying consecutive westward ridge jump/propagation events. It has been documented that at least in the last 20 million years these large asymmetries have resulted from repeated ridge propagation events, which formed the Bauer scarp and the Galapagos Rise [Goff and Cochran, 1996]. This is consistent with the results of the MELT experiments [Forsyth, et $a l ., 1998]$, which indicate that there is markedly more melt present beneath the western side of the East Pacific Rise than beneath the eastern side. The Pacific Superswell to the west $[M c N u t t$ and Judge, 1990], visible on our residual depth-anomaly maps (Fig. 11), also implies that the mantle is hotter west of the ridge, thus substantiating the idea that asymmetries in upper mantle 
temperature and partial melt concentration drive long-term asymmetries in crustal accretion more strongly than absolute ridge migration rates.

The most prominent negative residual depth anomalies we observe when using plate models, as opposed to thermal boundary layer models, for computing residual depth anomaly maps appear as blue/dark green colors on Figures $11 \mathrm{a}$ and b, corresponding to prominent negative depth anomalies in the range between 750 and $1500 \mathrm{~m}$ and more. They are observed just offshore the east coast of North America, northeast of Venezuela (southeast of the eastern Caribbean Lesser Antilles Arc), in the Gulf of Mexico, in the Argentine Basin in the southwestern South Atlantic, in the Bay of Bengal southeast of India, a north-south oriented swath between Australia and Antarctica, and the Philippine Sea as well as some smaller backarc basins offshore Southeast Asia, southwest of the Philippine Sea (see Gaina and Müller [2007] for more detailed discussion of depth anomalies in the southwest Pacific and southeast Asia).

We have labelled the areas outlined above in Fig. 11a, and assembled a set of maps of past subduction zone locations paired with seismic tomography cross sections from Ritsema and van Heijst [2000] and Ritsema et al.[2004] (Fig. 12). We choose this tomography model, because it is commonly used to compute surface dynamic topography driven by mantle convection [e.g. Conrad, et al., 2004; Steinberger, 2007].

The seismic tomography cross sections displayed in Fig. 12 allow us to divide the regional negative residual depth anomalies analyzed here into several groups. The depth anomalies off the east coast of the USA ((EC) and the Bay of Bengal (BB) are associated with Cretaceous (and older) subducted slab material in the lower mantle only, whereas the Gulf of Mexico (GM), the Argentine Basin $(\mathrm{AB})$, the "hourglass shaped" depth anomaly associated with the Australian Antarctic Discordance (AAD) and the Philippine Sea (PS) depth anomaly (Fig. 11a, b) are associated with subducted slab material both above and below the upper/lower mantle transition zone (Fig. 12). In the case of the Gulf of Mexico and the Philippine Sea, this reflects the 
presence of both Cretaceous and Tertiary subducted slab material (Fig. 12). At the AAD there is an absence of Tertiary slab material, and the reason that some Cretaceous slab material is still present in the upper mantle is rather that the southeast Indian Ridge, which is intersecting the subducted Phoenix slab material roughly at right angles, has drawn up some of the subducted slab material from just above the transition zone [Gurnis, et al., 1998]. What all the negative depth anomalies discussed above have in common is that they overlay slab burial grounds, where subducted slab material is imaged either in the upper or lower mantle, or both (Fig. 12, also see Fukao et al. [2001] for detailed subducted slab images in many of these areas).

The remaining oceanic depth anomalies discussed here, i.e. the area south of the Newfoundland margin, off the coast of Nova Scotia, including the Scotian Basin (here labelled NF, see also Conrad et al. [2004]) and parts of the Demerara Abyssal Plain (DA), are associated with positive shear-wave velocity anomalies in the upper mantle only. The upper mantle anomaly associated with the Demerara Abyssal Plain (DA) is clearly not related to the subducted Phoenix slab, which is imaged in the lower mantle further west (Fig. 12). It may be associated with Tertiary subduction along the Lesser Antilles Arc (see Mann et al.'s [2007] kinematic reconstructions for comparison), but the imaged fast upper mantle shear-wave anomaly appears to be offset to the southeast with respect to the reconstructed locations of the Lesser Antilles Trench (Fig. 12). In case of the depth anomaly off Newfoundland, the seismic tomography cross section clearly shows that the large negative velocity anomaly in the upper mantle underlying the area is not related to the subducted Farallon slab. Instead it forms a distinct separate upper mantle anomaly, which cannot be related to the history of subduction (Fig. 12).

Both the Newfoundland and Demerara oceanic residual depth anomalies and associated fast upper mantle shear wave anomalies may be related to edge-driven convection initiated at the boundaries between thick, stable continental lithosphere juxtaposed with thinner oceanic lithosphere, creating downwelling convective limbs in the upper-mantle, a mechanism proposed 
by King and Ritsema [2000] to create fast upper mantle seismic velocity anomalies bordering continents. This had also been suggested for the depth anomaly off Newfoundland by Conrad et al. [2004]. Our observations provide evidence that this mechanism may also play a role in creating oceanic basement depth anomalies elsewhere, e.g. in the Demerara Abyssal Plain area . Steinberger's [2007] recent work on global dynamic topography shows that the upper mantle shear wave anomaly underneath the Demerara Abyssal Plain as imaged by S20RTS [Ritsema and van Heijst, 2000; Ritsema et al., 2004] (Fig. 12) is modelled to result in negative dynamic topography in this area.

In fact all negative residual oceanic basement depth anomalies discussed here are characterized by downward directed vertical mantle flow at either the 410 or $660 \mathrm{~km}$ mantle transition zone, or both, as well as negative dynamic surface topography [Steinberger, 2007]. This suggests that dynamic surface topography caused by deep mantle flow associated with subducted slabs, as well as upper mantle edge-driven convection, plays a prominent role in producing oceanic basement depth anomalies.

\section{Conclusions}

Gridded oceanic crustal ages, spreading half-rates, asymmetries and depth anomalies combined with a global relative and absolute plate motion model have a wide range of applications. We have provided an example how these data sets can be used to decipher the origin of spreading asymmetries and basement depth anomalies. In the Pacific Ocean, our grids still represent a fairly simplified model of the age distribution of the ocean floor due to the large number of spreading ridge reorganizations that characterize the region, which have not yet been included in our model in their entirety. For instance, we hope to test Taylor's [2006] suggestion in the future that the Ontong Java, Manihiki and Hikurangi plateaus formed as one contiguous large igneous province. This scenario would add a spreading ridge between the Ontong Java and Manihiki plateaus some time after initial plateau formation. Exactly when this ridge may have existed and 
how it may have continued to the north and linked with either the Izanagi-Pacific or the Farallon Pacific ridge is currently not known. Due to the wide spacing of our isochrons and many remaining uncertainties in the observed age-area distribution in the Pacific, our isochrons in this region remain work in progress. We also hope to include revised isochrons for the central Indian Ocean in the next version of our digital grids.

\section{Acknowledgments}

This work builds upon a previous effort to construct digital gridded isochrons of the ocean floor, and this work would not have been possible without software that was developed and expanded over many years by Stuart Clark and James Boyden. The GMT software system from P. Wessel and W.H.F. Smith [1998] was invaluable in performing the age error analysis, and for producing the Figures. We thank Jerome Dyment and Doug Wilson for detailed reviews, which improved the paper considerably. The paper also benefited from many discussions with Mike Gurnis and a review of an early draft by Stefan Maus. We also thank Doug Wilson for providing digital data for some parts of the east Pacific. Special thanks go to John Tarduno for the time and effort he contributed as editor to provide constructive reviews and feedback.

\section{Appendix}

Digital grids of oceanic age, age uncertainty, spreading rates, spreading asymmetry and residual oceanic basement depth anomalies are available through the AuScope EarthByte web site www.earthbyte.org. 


\section{References}

Atwater, T., and J. Severinghaus (1990), Tectonic maps of the northeast Pacific, in The Eastern Pacific Ocean and Hawaii, edited by E. L. Winterer, et al., pp. 15-20, Geological Society of America, Boulder, Colorado.

Barker, P. F. (2001), Scotia Sea regional tectonic evolution: implications for mantle flow and palaeocirculation, Earth-Sci. Rev., 55, 1-39.

Barker, P. F., and I. A. Hill (1980), Asymmetric spreading in back-arc basins, Nature, 285, 652654.

Bernard, A., et al. (2005), Refined spreading history at the Southwest Indian Ridge for the last $96 \mathrm{Ma}$, with the aid of satellite gravity data Geophysical Journal International, 162, 765778.

Billen, M. I., and J. Stock (2000), Morphology and origin of the Osbourn Trough, Journal of Geophysical Research, 105, 13481-13489.

Bird, P. (2003), An updated digital model of plate boundaries, Geochemistry, Geophysics, Geosystems, 4, 1027, doi:1010.1029/2001GC000252.

Calcagno, P., and A. Cazanave (1994), Subsidence of the seafloor in the Atlantic and Pacific Oceans: regional and large-scale variations, Earth \& Planetary Science Letters, 126, 473 492.

Cande, S. C., and D. V. Kent (1995), Revised calibration of the geomagnetic polarity timescale for the Late Cretaceous and Cenozoic, Journal of Geophysical Research, 100, 60936095.

Cande, S. C., et al. (1995), Geophysics of the Pitman Fracture Zone and Pacific-Antarctic Plate Motions During the Cenozoic, Science, 270, 947-953.

Cande, S. C., et al. (2000), Cenozoic motion between East and West Antarctica, Nature, 404, 145-150.

Conrad, C. P., et al. (2004), Iceland, the Farallon Slab, and dynamic topography of the North Atlantic, Geology, 32, 177-180.

Crosby, A. G. (2007), Aspects of the relationship between depth and age on the Earth and Moon, $\mathrm{PhD}$ thesis, 220 pp, University of Cambridge, Cambridge.

Crosby, A. G., et al. (2006), The relationship between depth, age and gravity in the oceans, Geophys. Jour. Int., 166, 553-573.

Davey, F. J., et al. (2006), Extension in the western Ross Sea region - links between Adare Basin and Victoria Land basin, Geophysical Research Letters, 33, doi:10.1029/2006GL027383.

Divins, D. L. (2004), Total sediment thickness of the world's oceans and marginal seas, edited, National Geophysical Data Center.

Eagles, G., et al. (2005), Tectonic evolution of the west Scotia Sea, Journal of Geophysical Research-Solid Earth, 110, 2401-2401.

Eakins, B. W., and P. F. Lonsdale (2003), Structural patterns and tectonic history of the Bauer microplate, Eastern Tropical Pacific, Marine Geophysical Researches, 24, 171-205.

Forsyth, D. W., et al. (1998), Imaging the deep seismic structure beneath a mid-ocean ridge: The MELT experiment, Science, 280, 1215-1218. 
Fukao, Y., et al. (2001), Stagnant slabs in the upper and lower mantle transition region, Reviews of Geophysics, 39, 291-323.

Gaina, C., and R. D. Müller (2007), Cenozoic tectonic and depth/age evolution of the Indonesian gateway and associated back-arc basins, Earth Science Reviews, 83, 177-203.

Gaina, C., et al. (2003), Microcontinent formation around Australia, in Evolution and Dynamics of the Australian Plate, edited by H. R.R. and M. R.D., pp. 405-416, Geological Society of Australia Special Publication 22 and Geological Society of America Special Paper 372 .

Gaina, C., et al. (1998), The tectonic history of the Tasman Sea: a puzzle with 13 pieces, Journal of Geophysical Research, in press.

Gaina, C., et al. (1999), Evolution of the Louisiade triple junction, Journal of Geophysical Research-Solid Earth, 104, 12927-12939.

Gaina, C., et al. (2002), Late Cretaceous-Cenozoic deformation of northeast Asia, Earth and Planetary Science Letters, 197, 273-286.

Gaina, C., et al. (2007), Cretaceous-Tertiary plate boundaries in the North Atlantic and Arctic, paper presented at European Geoscience Union Meeting, European Geoscience Union, Vienna.

Garfunkel, Z. (2004), Origin of the Eastern Mediterranean basin: a reevaluation, Tectonophysics, $391,11-34$.

Goff, J. A., and J. R. Cochran (1996), The Bauer scarp ridge jump: A complex tectonic sequence revealed in satellite altimetry, Earth and Planetary Science Letters, 141, 21-33.

Gradstein, F. M., et al. (1994), A Mesozoic time scale, Journal of Geophysical Research-Solid Earth, 99, 24051-24074.

Gurnis, M., et al. (1998), Dynamics of Cretaceous to the Present Vertical Motion of Australia and the Origin of the Australian-Antarctic Discordance, Science, in press.

Hayes, D. E. (1988), Age-depth relationships and depth anomalies in the southeast Indian Ocean and south Atlantic Ocean, Journal of Geophysical Research, 93, 2937-2954.

Heine, C., and R. D. Müller (2005), Late Jurassic rifting along the Australian Northwest Shelf: margin geometry and spreading ridge configuration, Australian Journal of Earth Science, 52, 27-39.

Heine, C., et al. (2004), Reconstructing the Lost Eastern Tethys Ocean Basin: Convergence history of the SE Asian margin and marine gateways, in Continent-Ocean Interactions within East Asian Marginal Seas, AGU Geophysical Monograph, edited by P. D. Clift, et al., pp. 37-54, American Geophysical Union, Washington.

Hohertz, W. L., and R. L. Carlson (1998), An independent test of thermal subsidence and asthenosphere flow beneath the Argentine Basin, Earth and Planetary Science Letters, $161,73-83$.

King, S. D., and J. Ritsema (2000), African hot spot volcanism: Small-scale convection in the upper mantle beneath cratons, Science, 290, 1137-1140.

König, M., and W. Jokat (2006), The Mesozoic breakup of the Weddell Sea, Journal of Geophysical Research-Solid Earth, 111, 12102-12102. 
Lapierre, H., et al. (2007), The Mamonia Complex (SW Cyprus) revisited: remnant of Late Triassic intra-oceanic volcanism along the Tethyan southwestern passive margin, Geological Magazine, 144, 1-19.

Lonsdale, P. F. (1988), Paleogene history of the Kula Plate; offshore evidence and onshore implications, Bulletin of the Geological Society of America, 100, 733-754.

Mann, P., et al. (2007), Overview of plate tectonic history and its unresolved tectonic problems in Central America: Geology, Resources and Hazards, edited by J. Bundschuh and G. E. Alvarado, pp. 205-241, Taylor and Francis.

Marks, K. M., and A. A. Tikku (2001), Cretaceous reconstructions of East Antarctica, Africa and Madagascar, Earth \& Planetary Science Letters, 186, 479-495.

McNutt, M. K., and A. V. Judge (1990), The superswell and mantly dynamics beneath the South Pacific, Science, 248, 933-1048.

Mihut, D. (1997), Breakup and Mesozoic seafloor spreading between the Australian and Indian plates, Ph.D. thesis, 223 pp, The University of Sydney, Sydney.

Mihut, D., and R. D. Müller (1998), Volcanic margin formation and Mesozoic rift propagators in the Cuvier abyssal plain off Western Australia, Journal of Geophysical Research, in press.

Müller, R. D., et al. (1998a), New constraints on the Late Cretaceous/Tertiary plate tectonic evolution of the Caribbean, in Caribbean sedimentary basins, edited by P. Mann, Elsevier.

Müller, R. D., et al. (2000), Mesozoic/Cenozoic tectonic events around Australia, in The history and dynamics of global plate motions, edited by M. A. Richards, et al., pp. 161-188, American Geophysical Union, Washington, DC.

Müller, R. D., et al. (2007), Eocene to Miocene geometry of the West Antarctic Rift System, Australian Journal of Earth Science, 54, 1033-1045.

Müller, R. D., et al. (1998b), Asymmetic seafloor spreading expresses ridge-plume interactions, Nature, 396, 455-459.

Müller, R. D., et al. (1997), Digital isochrons of the world's ocean floor, Journal of Geophysical Research, 102, 3211-3214.

Munschy, M., et al. (1996), Evolution tectonique de la region Tuamotu, ocean Pacifique central, C.A. Acad. Sci. Paris, t. 323, serie II a, 941-948.

Nakanishi, M., et al. (1989), Mesozoic magnetic anomaly lineations and seafloor spreading history of the northwestern Pacific, J. Geophys. Res., 89, 15,437-415,462.

Nakanishi, M., et al. (1992), A new Mesozoic isochron chart of the northwestern Pacific Ocean: paleomagnetic and tectonic implications, Geophysical Research Letters, 19, 693-696.

Nankivell, A. P. (1998), Tectonic evolution of the Southern Ocean between Antarctica, South America and Africa over the past $84 \mathrm{Ma}$, Ph.D. thesis, University of Oxford, Oxford.

Phipps Morgan, J., and W. H. F. Smith (1992), Flattening of the sea-floor depth-age curve as a response to asthenospheric flow, Nature (London), 359, 524-527.

Pindell, J. L., and S. F. Barrett (1987), Geological evolution of the Caribbean Region: A plate tectonic perspective, in The Caribbean Region, edited, Geol. Soc. America, Boulder, Colorado. 
Priestley, K., and D. McKenzie (2006), The thermal structure of the lithosphere from shear wave velocities, Earth and Planetary Science Letters, 244, 285-301.

Reid, I., and H. R. Jackson (1997), Crustal structure of northern Baffin Bay: Seismic refraction results and tectonic implications, Journal of Geophysical Research - Solid Earth, 102, 523-542.

Ritsema, J., et al. (2004), Global transition zone tomography, Journal of Geophysical Research, 109, 10.1029/2003JB002610.

Ritsema, J., and H. J. Van Heijst (2000), Seismic imaging of structural heterogeneity in Earth's mantle: Evidence for large-scale mantle flow Science Progress, 83, 243-259.

Robb, M. S., et al. (2005), Re-examination of the magnetic lineations of the Gascoyne and Cuvier Abyssal Plains, off NW Australia Geophysical Journal International, 163, 42-55.

Ross, M. I., and C. R. Scotese (1988), A hierarchical tectonic model of the Gulf of Mexico and Caribbean region, Tectonophysics, 155, 139-168.

Sandwell, D. T., and W. H. F. Smith (1997), Marine gravity anomaly from ERS-1, Geosat and satellite altimetry, Journal of Geophysical Research, 10039-10045.

Sdrolias, M., and R. D. Müller (2006), Controls on back-arc basin formation, Geochemistry Geophysics and Geosystems, 7.

Sdrolias, M., et al. (2003a), Tectonic Evolution of the SW Pacific Using Constraints from Backarc Basins, in Evolution and Dynamics of the Australian Plate, edited by H. R.R. and M. R.D., Geological Society of Australia Special Publication 22 and Geological Society of America Special Paper.

Sdrolias, M., et al. (2003b), An Expression of Philippine Plate Rotation: the Parece Vela and Shikoku Basins, Tectonophysics, 394, 69-86.

Sleep, N. H. (2002), Ridge-crossing mantle plumes and gaps in tracks, Geochemistry Geophysics Geosystems, 3, 8505-8505.

Sleep, N. H. (2006), Mantle plumes from top to bottom, Earth-Sci. Rev., 77, 231-271.

Smith, W. H. F., and D. T. Sandwell (1994), Bathymetric prediction from dense satellite altimetry and sparse shipboard bathymetry, Journal of Geophysical Research, 99, 2180321824.

Sokolov, S. D., et al. (2002), South Anyui suture, northeast Arctic Russia: Facts and Problems, in Tectonic Evolution of the Bering Shelf-Chukchi Sea-Arctic Margin and adjacent landmasses, Geological Society of America Special Paper, edited by E. L. Miller, et al., pp. 209-224, Geological Society of America, Boulder, CO.

Speranza, F., et al. (2002), Age of the Corsica - Sardinia rotation and Liguro - Provencal Basin spreading: new paleomagnetic and Ar/Ar evidence, Tectonophysics, 347, 231-251.

Stampfli, G. M., and G. D. Borel (2002), A plate tectonic model for the Paleozoic and Mesozoic constrained by dynamic plate boundaries and restored synthetic oceanic isochrons, Earth and Planetary Science Letters, 196, 17-33.

Stein, C. A., and S. Stein (1992), A model for the global variation in oceanic depth and heat flow with lithospheric age, Nature, 359.

Steinberger, B. (2000), Plumes in a convecting mantle: Models and observations for individual hotspots, Journal Of Geophysical Research-Solid Earth, 105, 11127-11152. 
Steinberger, B. (2007), Effects of latent heat release at phase boundaries on flow in the Earth's mantle, phase boundary topography and dynamic topography at the Earth's surface, Physics of the Earth and Planetary Interiors, 164, 2-20.

Sykes, T. J. S. (1996), A correction for sediment load upon the ocean floor: Uniform versus varying sediment density estimations - Implications for isostatic correction, Marine Geology, 133, 35-49.

Taylor, B. (2006), The single largest oceanic plateau: Ontong Java-Manihiki-Hikurangi, Earth and Planetary Science Letters, 241, 372-380.

Wessel, P., and W. H. F. Smith (1998), New, improved version of Generic Mapping Tools released, EOS Transactions, AGU, 579.

Wilson, D. S. (1996), Fastest known spreading on the Miocene Cocos-Pacific plate boundary, Geophys Res Lett, 23, 3003-3006. 


\section{Figure Captions}

Fig. 1. (a) Age-area distribution of the ocean floor and (b) gridded age uncertainties, Molleweide projection. Continental margins are medium gray and continents light gray. Plate boundaries (black lines) are from Bird [2003].

Fig. 2. Distribution of age observations (marine magnetic anomaly identifications, rotated (red) and as observed in black), Molleweide projection.

Fig. 3. (a) Half-spreading rates and (b) percentage of crustal accretion of conjugate plates with hotspot locations [Steinberger, 2000] overlain as open circles. Roughly symmetric spreading is expressed by green colors, resulting in a distribution of $50 \%$ of accreted ocean crust on both conjugate plates, respectively. Deficits in accretion (blue) are paired with areas showing excess accretion. For a large portion of the Pacific Ocean conjugate plates of the Pacific Plate have been subducted. Crustal accretion percentages for this area are therefore not shown. Plate boundaries are from Bird [2003], Molleweide projection

Fig. 4. Oceanic lithospheric age (top), seafloor spreading half-rates (middle) and crustal accretion asymmetries (bottom) of conjugate plates in the North Atlantic, illuminated by marine gravity anomalies [Sandwell and Smith, 1997]. The isochrons shown correspond to chrons 5o (10.9 Ma), 6o (20.1 Ma), 13y (33.1 Ma), 18o (40.1 Ma), 21o (47.9 Ma), 25y (55.9 Ma), 31y (67.7 Ma), 34y (83.5 Ma), M0 (120.4 Ma), M4 (126.7 Ma), M10 (131.9 Ma), M16 (139.6 Ma), M21 (147.7 Ma), and M25 (154.3 Ma). The only exception is the Norwegian Greenland Sea, where the oldest isochron corresponds to chron 24o (53,3 Ma). Active spreading ridges are bold black lines, whereas extinct ridges are colored magenta on the age map and white on the spreading rate and asymmetry maps. Continental margins are medium gray and continents light gray. Hotspot locations are indicated by black stars. LP: Ligurian-Provencale Basin, IS: Ionian Sea, EM: East Mediterranean Sea. Spherical Mercator projection. 
Fig. 5. Oceanic lithospheric age (top), seafloor spreading half-rates (middle) and crustal accretion asymmetries (bottom) in the South Atlantic, Scotia Sea and northern Weddell Sea. Line and symbol plotting conventions as in Fig. 4. TC: Tristan Da Cunha hotspot, D: Discovery hotspot.

Fig. 6. Oceanic lithospheric age (top), seafloor spreading half-rates (middle) and crustal accretion asymmetries (bottom) in the Indian Ocean and Tasman/Coral seas. Line and symbol plotting conventions as in Fig. 3. However, in Tasman/Coral seas isochrons are shown for chrons 24y (52.4 Ma), 24o (53.3 Ma), 25y (55.9 Ma), 26o (57.9 Ma), 27o (61.3 Ma), 28o (63.6 Мa), 29y (64.7 Ma), 30y (65.6 Ma), 31o (68.7 Ma), 32y (71.1 Ma), 33y (73.6 Ma), 33o (79.1 Ma), 34 (83.5 Ma), following Gaina et al. [1998; 1999]. Other line and symbol plotting conventions as in Fig. 4. SB: Somali Basin, MOB: Mozambique Basin, RL: Riiser-Larsen Sea, EB: Elan Bank, KP: Kerguelen Plateau, WB: Wharton Basin, AP: Argo Abyssal Plain, GP: Gascoyne Abyssal Plain, CP: Cuvier Abyssal Plain, PA: Perth Abyssal Plain, CS: Coral Sea, TS: Tasman Sea. Bold arrows indicate directions of major ridge jumps towards the central Indian Ocean, leaving extinct ridges in the Mascarene Basin (MAB), Enderby Basin and Perth Abyssal Plain (PA).

Fig. 7. Oceanic lithospheric age (top), seafloor spreading half-rates (middle) and crustal accretion asymmetries (bottom) in the south Pacific Ocean. Line and symbol plotting conventions as in Fig. 4. OT: Osbourne Trough, AT: Adare Trough, EPR: East Pacific Rise.

Fig. 8. Oceanic lithospheric age (top), seafloor spreading half-rates (middle) and crustal accretion asymmetries (bottom) in the north Pacific Ocean. Line and symbol plotting conventions as in Fig. 4. GM: Gulf of Mexico, CT: Cayman Trough.

Fig. 9. Oceanic lithospheric age (top), seafloor spreading half-rates (middle) and crustal accretion asymmetries (bottom) in the west Pacific Ocean. Line and symbol plotting conventions as in Fig. 4, except for in back-arc basins, where the following isochrons are shown: 
West Phillipine Basin (18y, 20o, 21o, 24o, 26o), Caroline Sea (8o, 10o, 11o, 13y, 15o, 16y), Ayu Trough (3o, 5o), Parece Vela/Shikoku Basin (5Dy, 6o, 6By, 7o, 8o, 9o), Mariana Trough (1o, 2Ao, 3o), South China Sea (5Dy, 6o, 6By, 7o, 8o, 19o, 11o), Celebes Sea (16o, 17o, 18o, 19o, 21o), Sulu Sea (3o, 5o), South Fiji Basin (7o, 8o, 9o, 10o, 11o), North Fiji Basin (1o), Solomon Sea (17o, 18o), North Loyalty Basin (16y, 17o, 18o, 20o), Lau Basin (1o, 2Ao, 3o). SCS: South China Sea, SS: Solomon Sea, CS: Celebes Sea, BS: Bismark Sea, PS: Philippine Sea, AT: Ayu Trough, CA: Caroline Sea, PVB: Parece Vela Basin, SB: Shikoku Basin, MT: Marianas Trough, SO: Solomon Sea, CO: Coral Sea, LO: North Loyalty Basin, NF: North Fiji Basin, SF: South Fiji Basin, LB: Lau Basin.

Fig. 10. Age-depth curves from the GDH-1 plate model [Stein and Stein, 1992], from Crosby's [2007] plate model including decaying oscillations for basement depths of ocean floor older than 80 million years, modelled by a damped sinusoidal perturbation and from Crosby et al.'s [2006] North Pacific thermal boundary layer model (depth $=-2527 \mathrm{~m}-336 \sqrt{\text { age }})$, overlain over the median global oceanic basement depths in 10 million year bins (circles) from Crosby [2007] with bars indicating the upper and lower quartile depths.

Fig. 11. Residual basement depth grids computed by calculating the difference between the predicted basement depth from applying the GDH-1 model [Stein and Stein, 1992] (a) Crosby's [2007] plate model (b) and Crosby et al's [2006] North Pacific thermal boundary layer model to the age-area distribution from Fig. 1a and the sediment unloaded basement depth. Molleweide projection. Major negative residual basement depth anomalies are labelled as follows (see Fig. 12 for corresponding mantle seismic tomography cross sections: NF - Newfoundland, EC - US East Coast, GM - Gulf of Mexico, DA - Demerara Abyssal Plain, AB - Argentine basin, BB Bay of Bengal, PS - Philippine Sea, AAD - Australian Antarctic Discordant Zone.

Fig. 12. Colour coded reconstructed subduction zone locations from 140 Ma to present, based on rotations in Supp. Table 1, on orthographic maps overlain over continental outlines (black) and 
present-day plate boundaries (gray) paired with S20RTS mantle seismic shear wave anomaly cross sections from Ritsema and van Heijst [2000] and Ritsema et al.[2004], centered on negative residual depth anomalies for the nine selected regions and plotted roughly perpendicular to the regional strike of paleo-subduction zone locations. The centers of map/cross-section pairs roughly correspond to centers of negative residual depth anomalies labelled on Fig. 11a (NF Newfoundland, EC - US East Coast, GM - Gulf of Mexico, DA - Demerara Abyssal Plain, AB - Argentine basin, BB - Bay of Bengal, PS - Philippine Sea, AAD - Australian Antarctic Discordant Zone - here two profiles are shown, one on the Australian and one on the Antarctic side of the AAD); $\mathrm{TZ}$ - transition zone, $\mathrm{CMB}$ - core-mantle boundary. Seismic tomography profile locations are outlined on orthographic maps (left) as bold dark blue lines with white circles outlining profile end-points and respective mid-point. Note that all regional oceanic negative depth anomalies outlined on Fig. 11a (roughly corresponding to mid-points of profiles) are associated with fast shear-wave anomalies in either the upper mantle, lower mantle, or both. See text for discussion. 


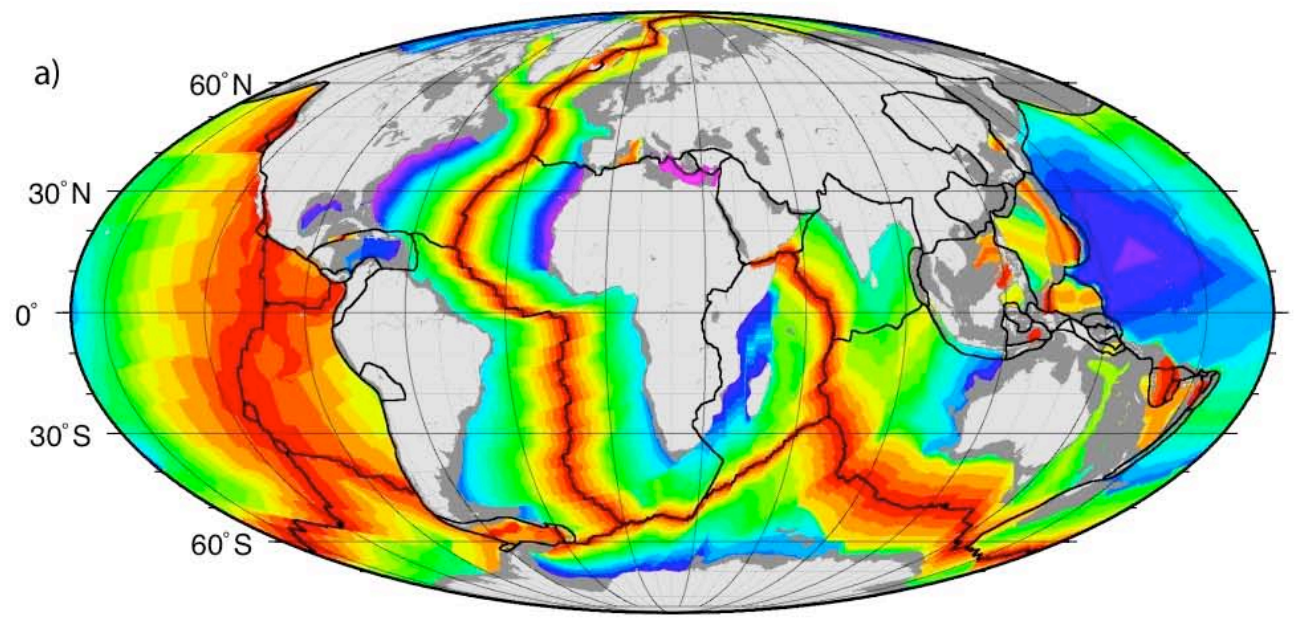

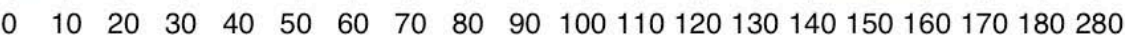

Age of Oceanic Lithosphere [m.y.]
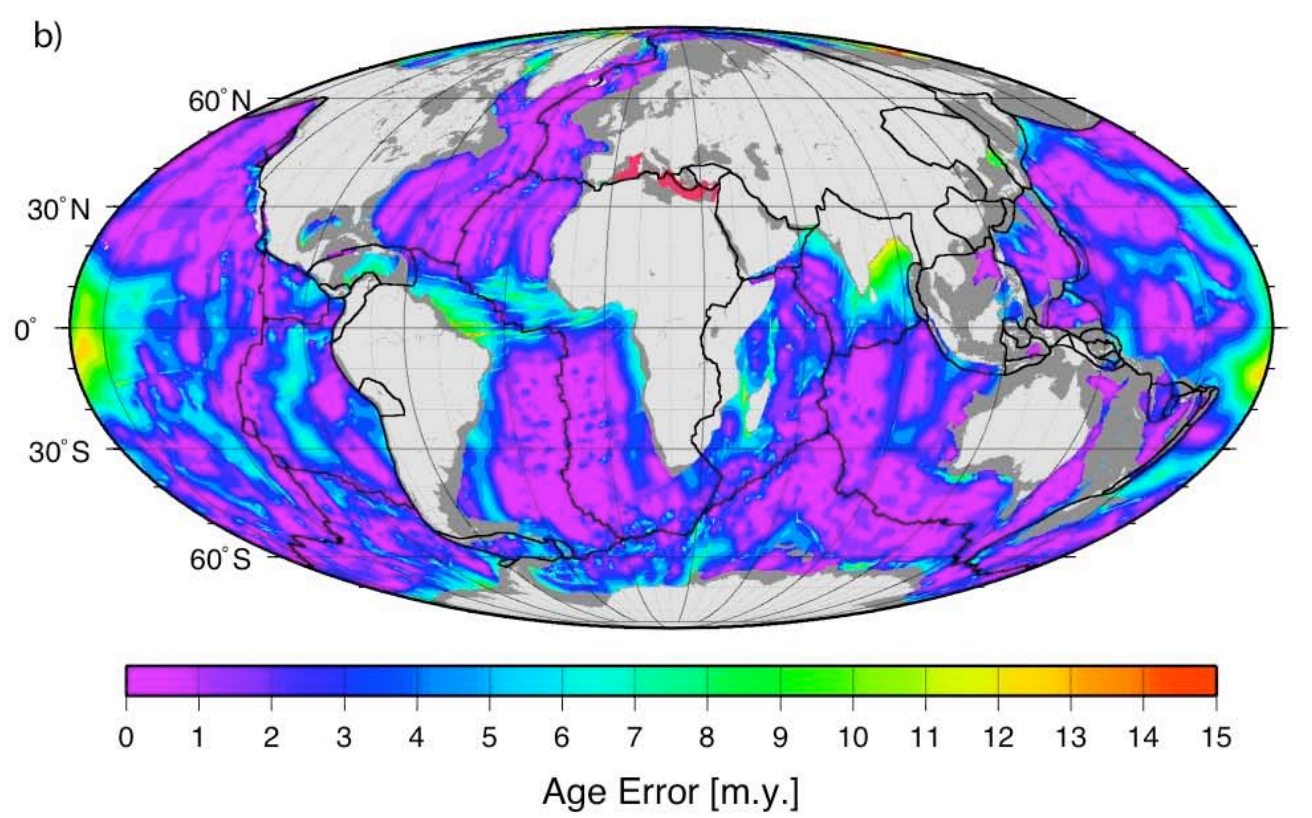


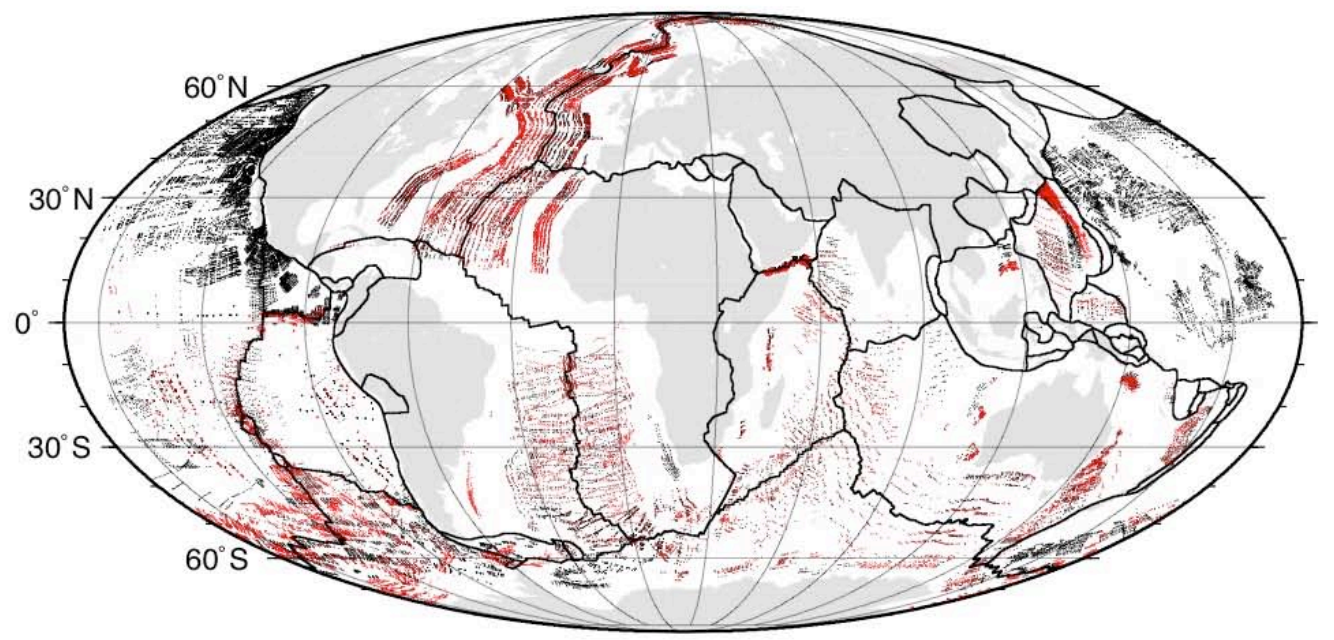



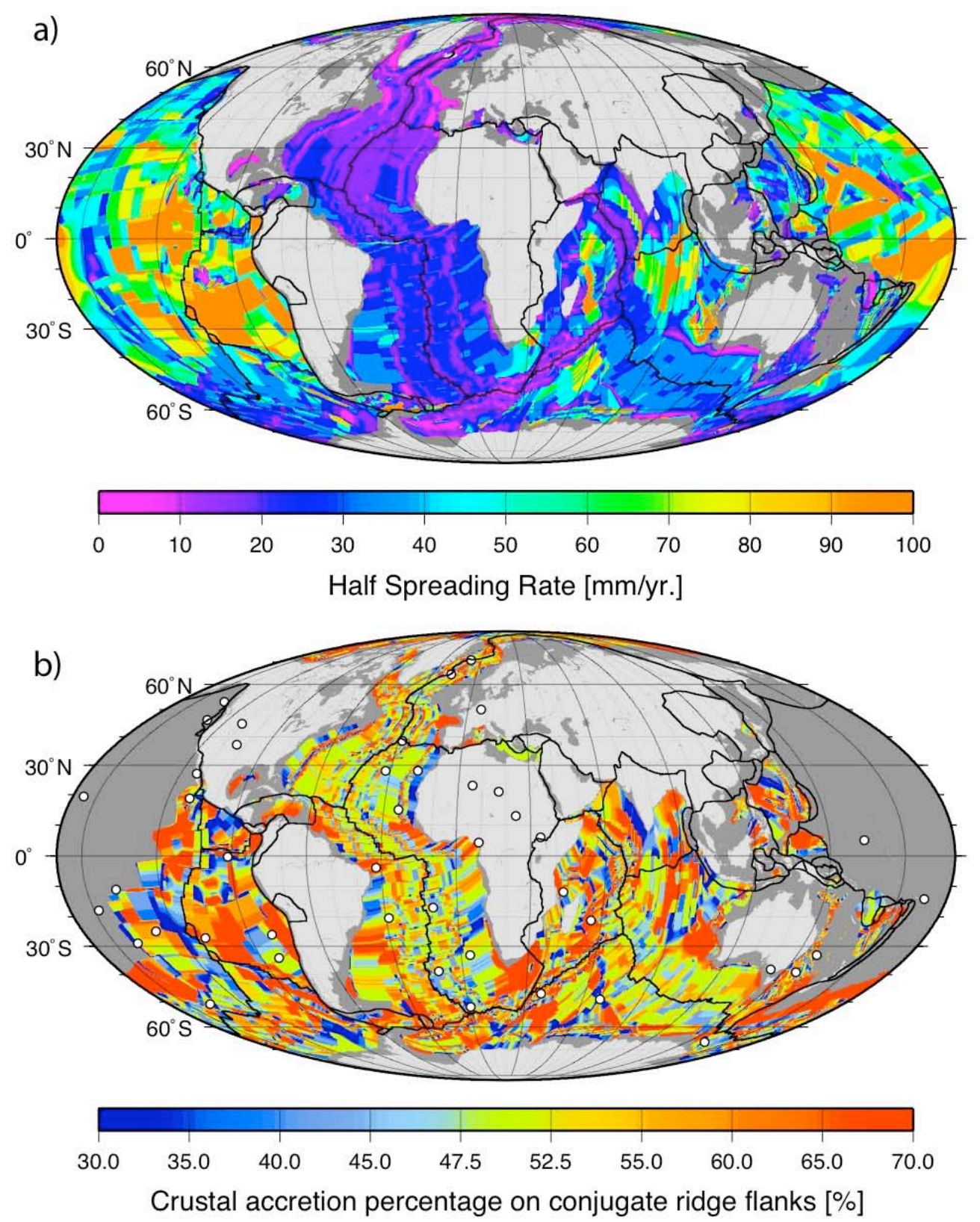


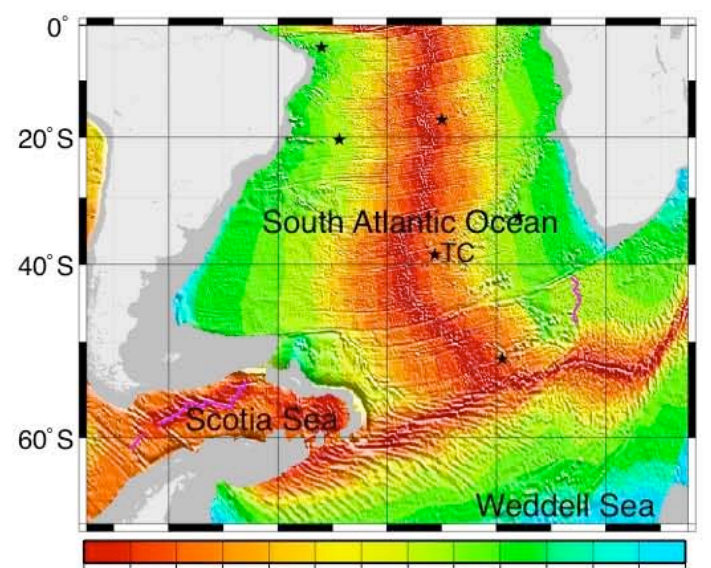

$0 \quad 10.920 .133 .140 .147 .955 .967 .783 .5100120 .4{ }^{131.9}$ Age of Oceanic Lithosphere [m.y.]
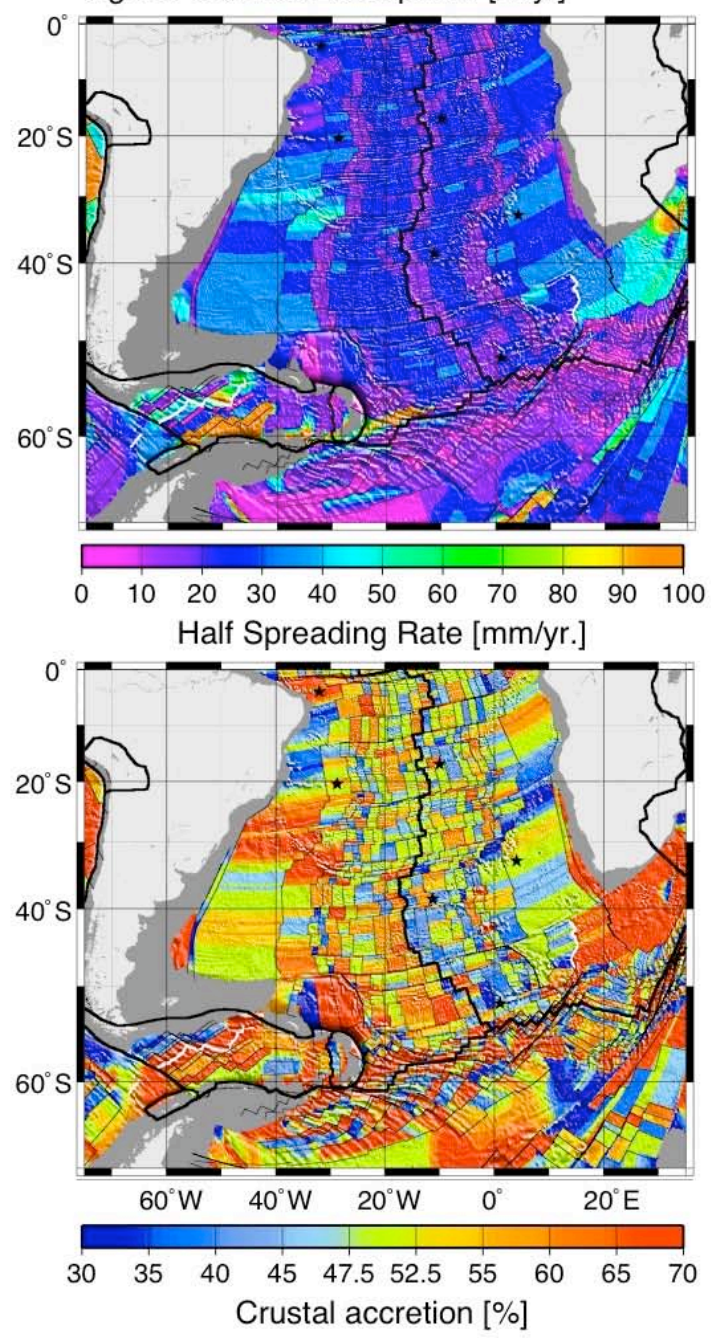


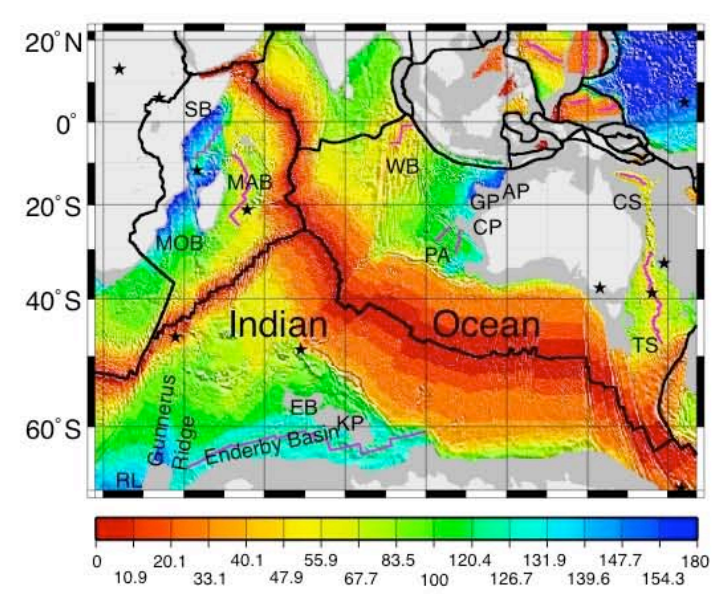

Age of Oceanic Lithosphere [m.y.]

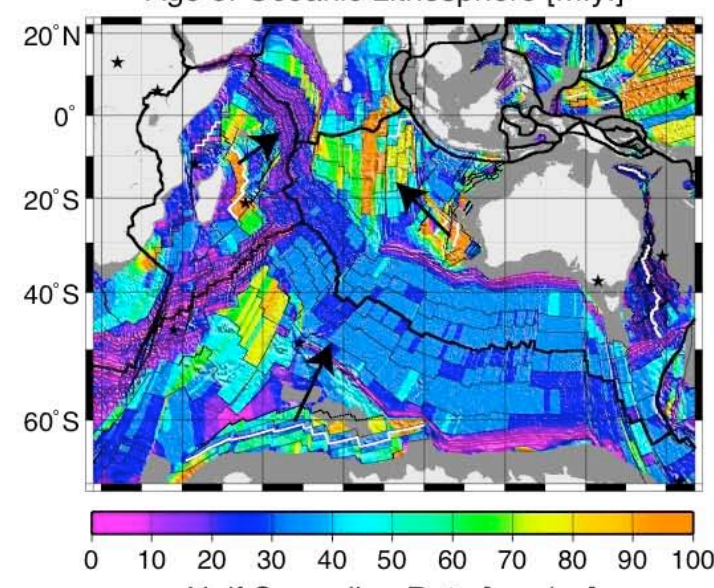

Half Spreading Rate [mm/yr.]

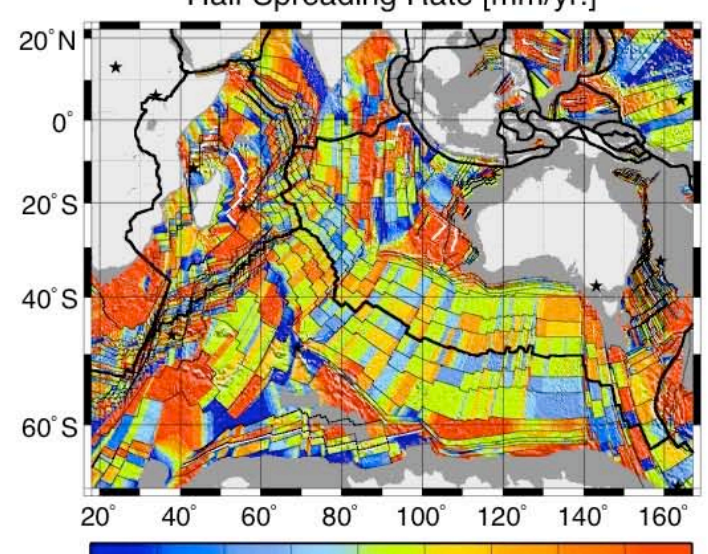

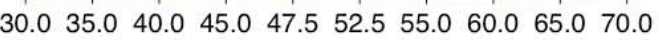
Crustal accretion [\%] 


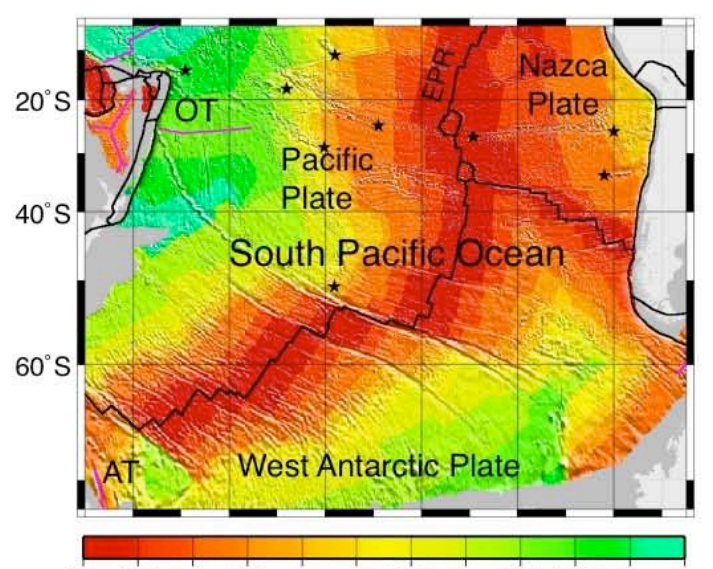

$\begin{array}{llllllllll}0.0 & 10.9 & 20.1 & 33.1 & 40.1 & 47.9 & 55.9 & 67.7 & 83.5 & 100.0120 .4126 .7\end{array}$ Age of Oceanic Lithosphere [m.y.]

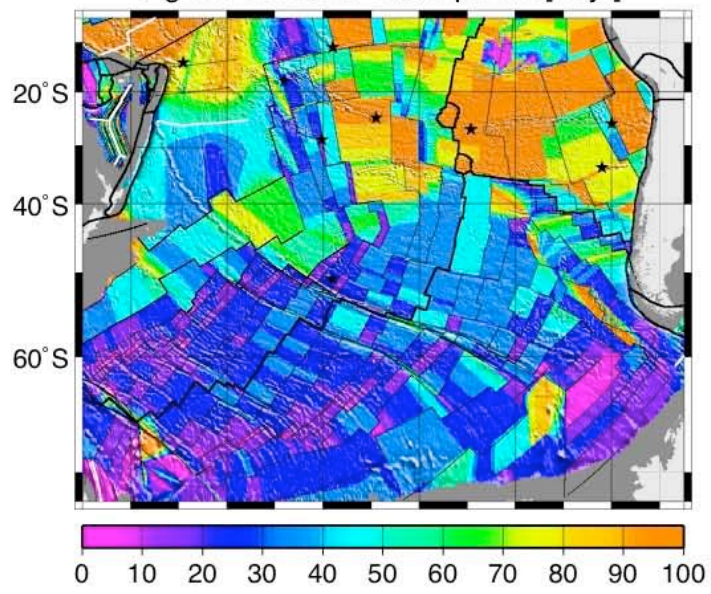
Half Spreading Rate [mm/yr.]

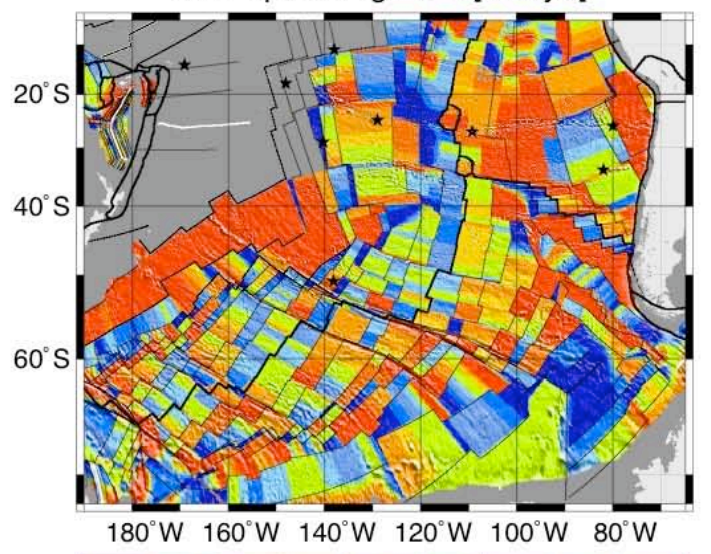

$\begin{array}{llllllllll}30.0 & 35.0 & 40.0 & 45.0 & 47.5 & 52.5 & 55.0 & 60.0 & 65.0 & 70.0\end{array}$ Crustal accretion [\%] 

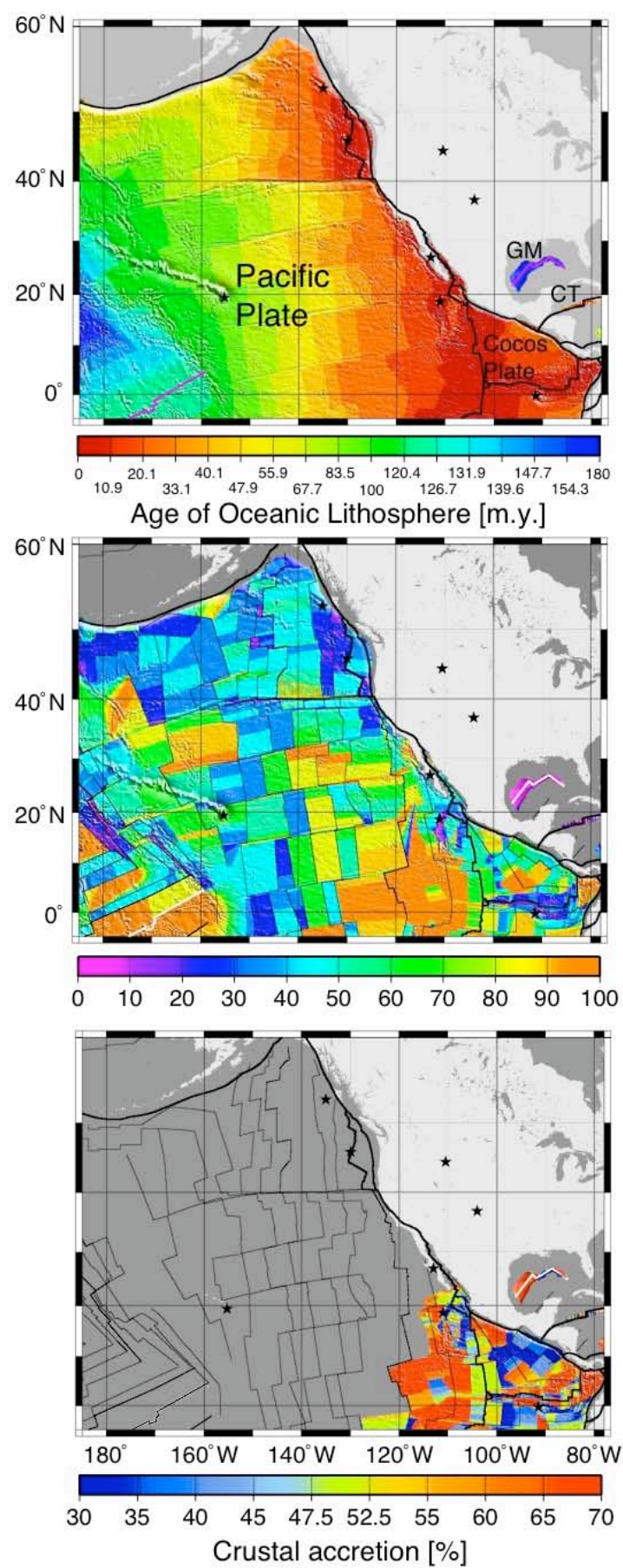


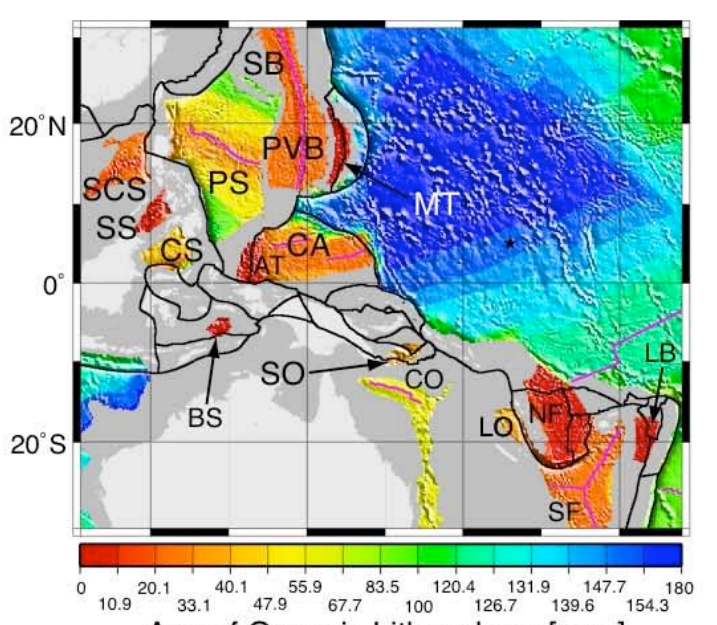

Age of Oceanic Lithosphere [m.y.]

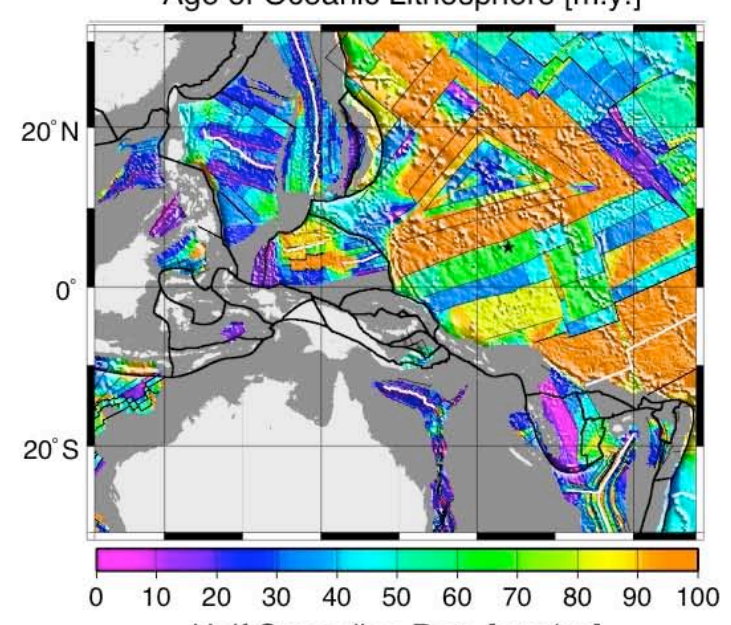
Half Spreading Rate [mm/yr.]

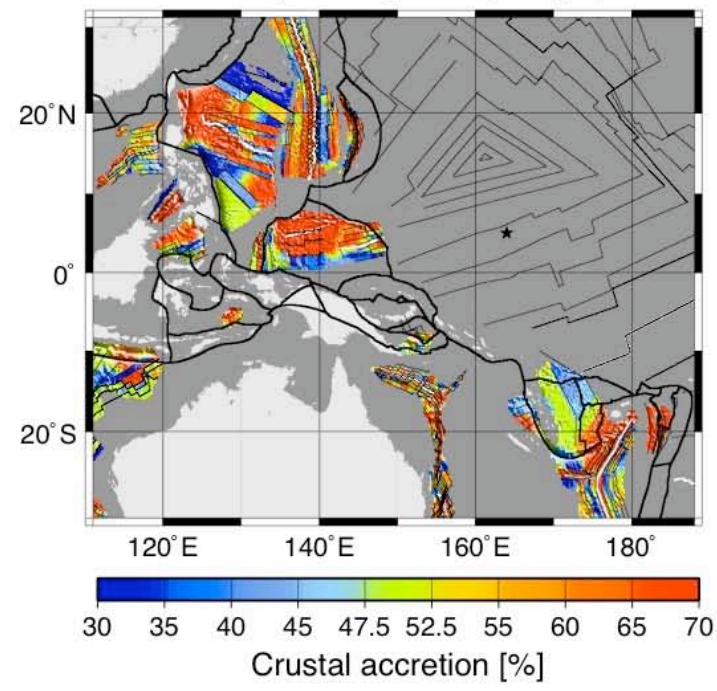




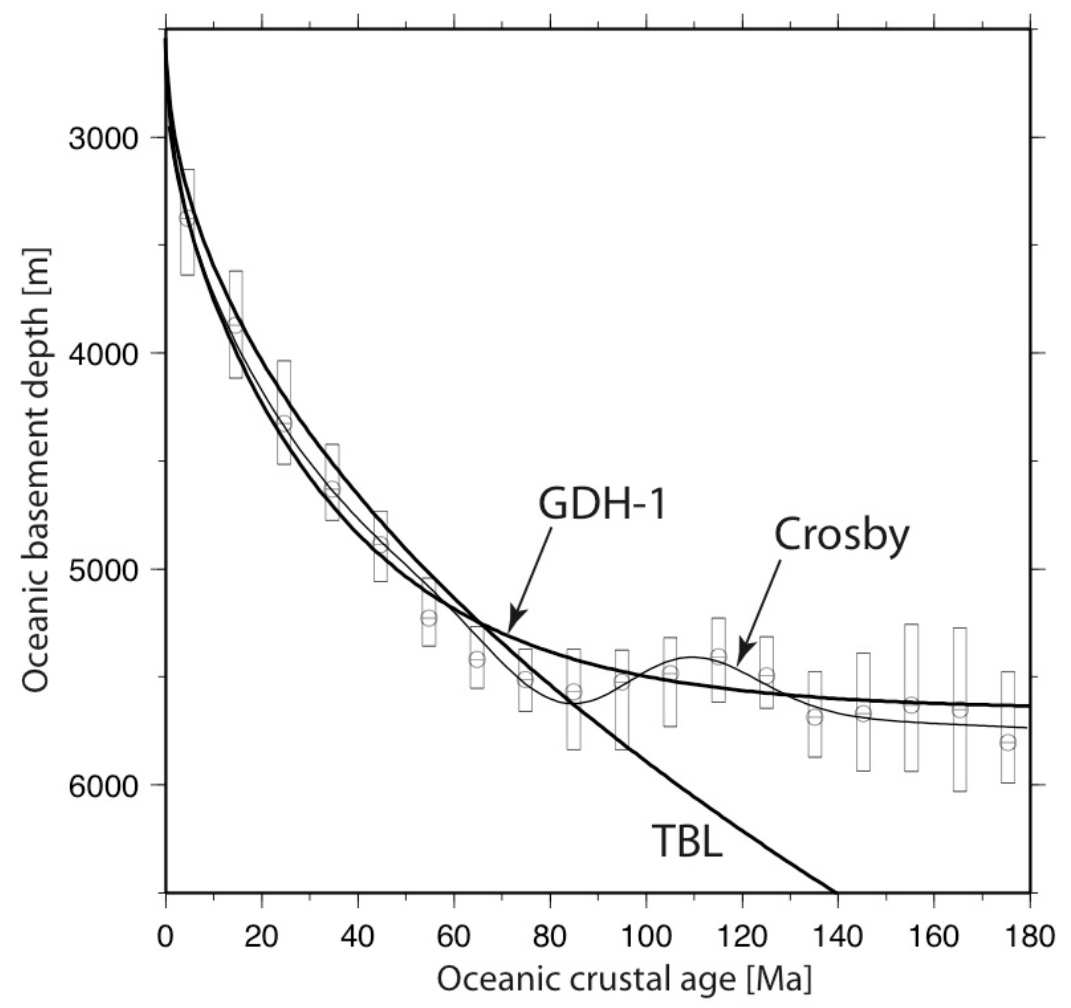



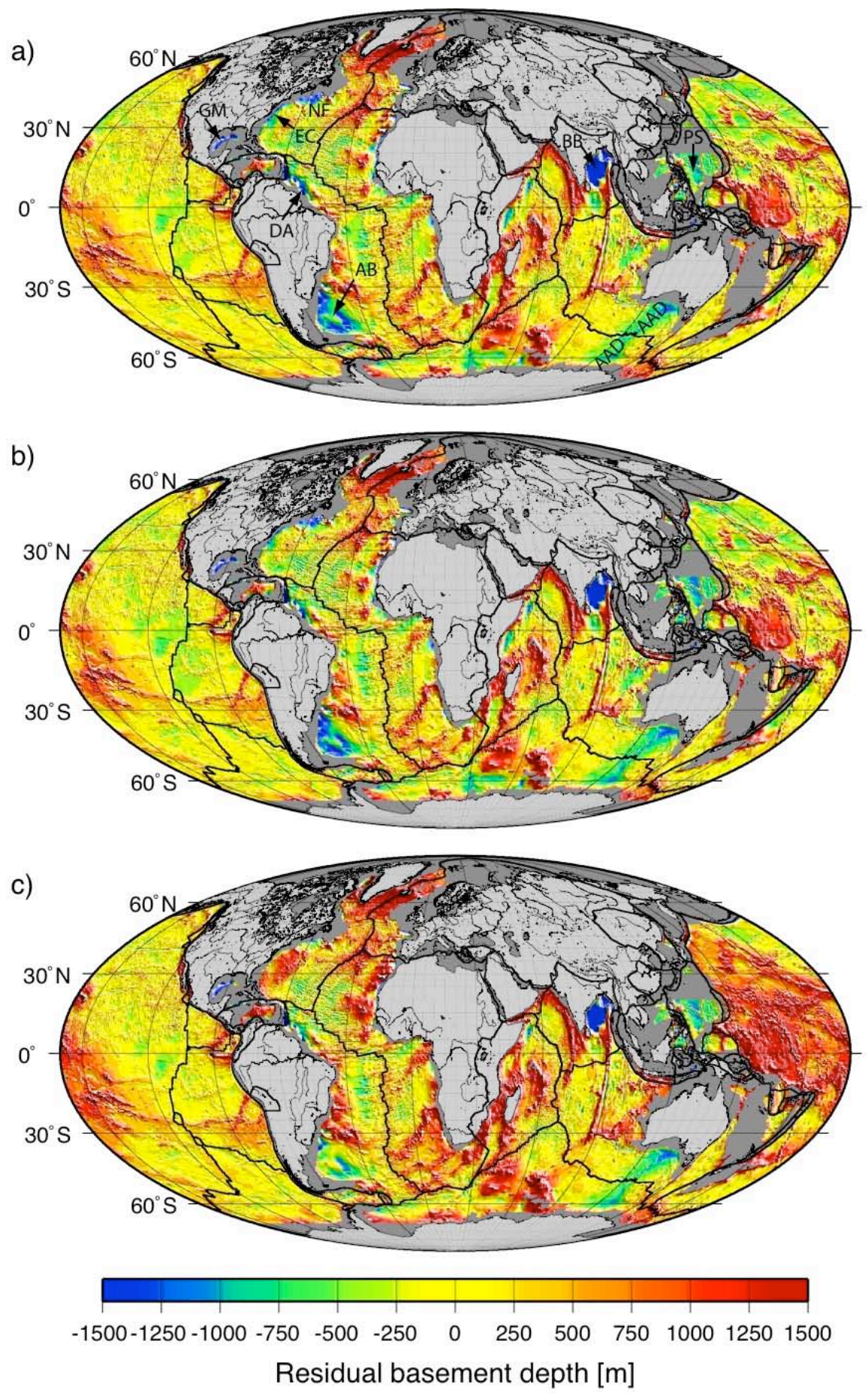


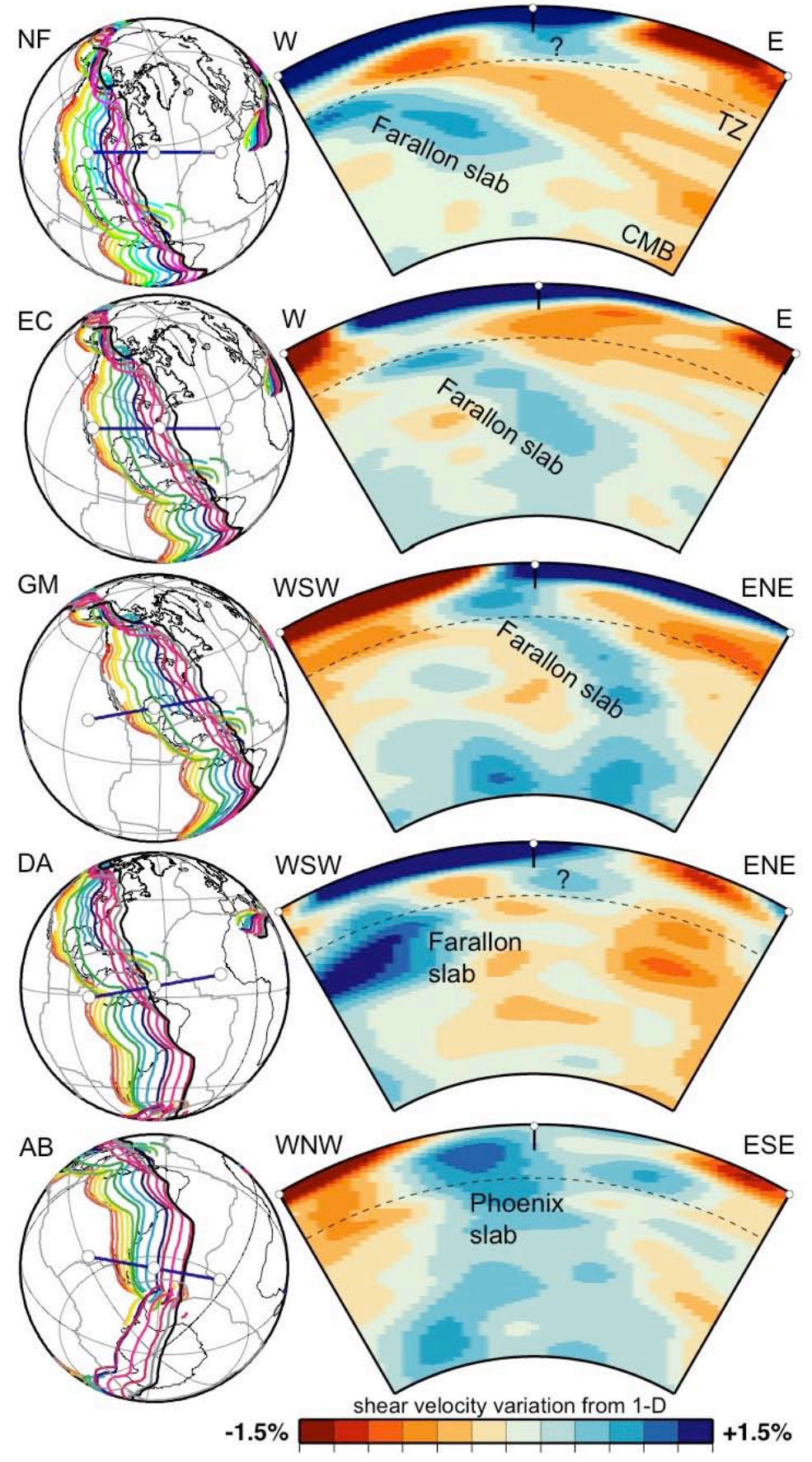

$10 \quad 20 \quad 30 \quad 40 \quad 50 \quad 60 \quad 70 \quad 80 \quad 90100110120130140 \mathrm{Ma}$

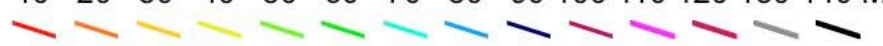

Subduction zone locations in 10 my intervals in mantle reference frame 


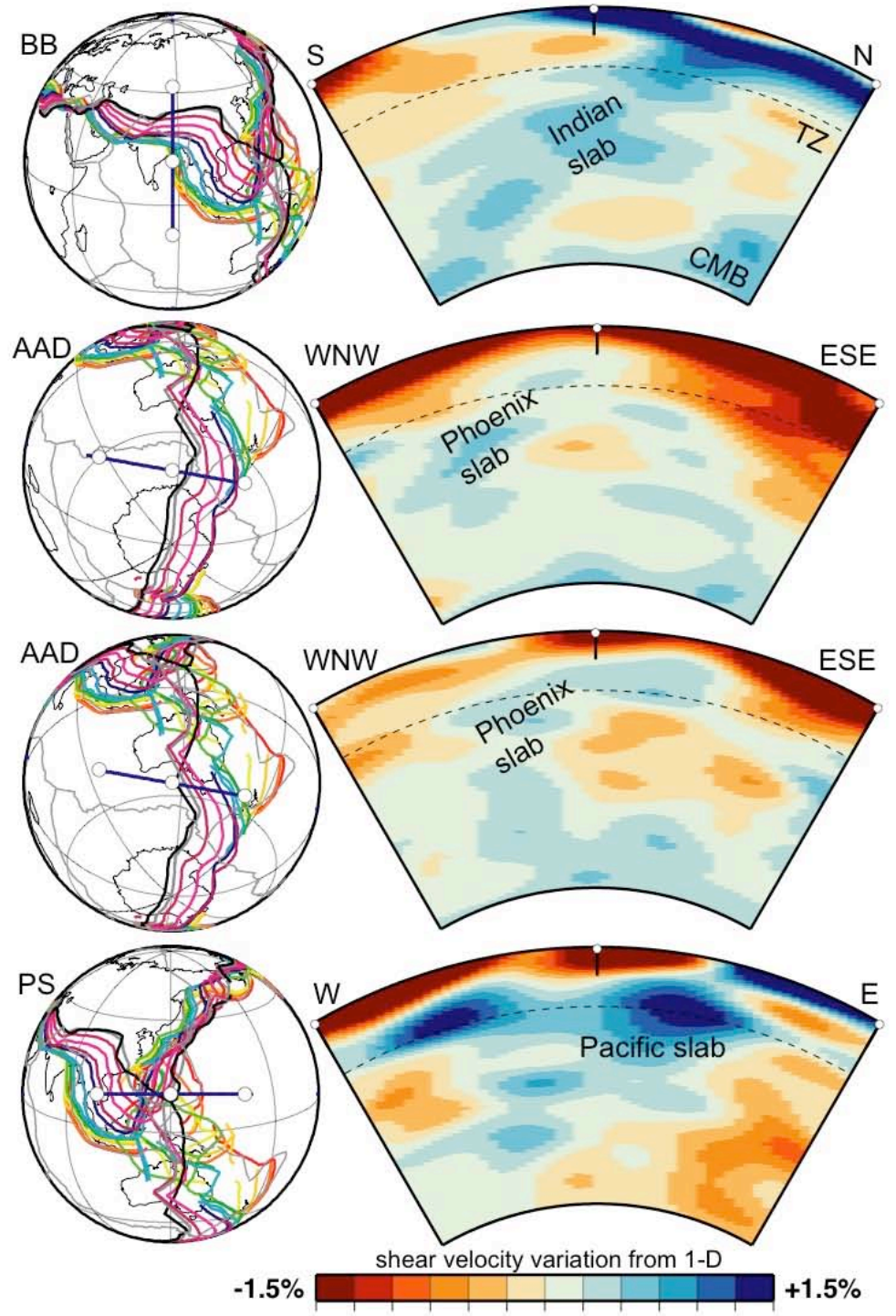

$10 \quad 20 \quad 30 \quad 40 \quad 50 \quad 60 \quad 70 \quad 80 \quad 90100110120130140 \mathrm{Ma}$

Subduction zone locations in 10 my intervals in mantle reference frame 